Article

\title{
Geochemistry and Zircon U-Pb Geochronology of the Zhuxi Granites in the Jingdezhen Area, Jiangxi Province, China: Implications for the Mesozoic Tectonic Development of South China
}

\author{
Hailong Huo ${ }^{1,2}$, Da Zhang ${ }^{2, *}$, Zhengle Chen ${ }^{1,3, * \mathbb{D}}$, Yongjun $\mathrm{Di}^{2}$, Xiaolong $\mathrm{He}^{2}$, $\mathrm{Ning} \mathrm{Li}^{2}$ and Bojie Hu ${ }^{2}$ \\ 1 Institute of Geomechanics, Chinese Academy of Geological Sciences, Beijing 100081, China; \\ huohailong2012@163.com \\ 2 School of Earth Sciences and Resources, China University of Geosciences, Beijing 100083, China; \\ diyongjun@cugb.edu.cn (Y.D.); hexiaolong@cugb.edu.cn (X.H.); lining@tyut.edu.cn (N.L.); \\ 3001180122@cugb.edu.cn (B.H.) \\ 3 School of Earth Sciences, East China University of Technology, Nanchang 330013, China \\ * Correspondence: zhangda@cugb.edu.cn (D.Z.); chenzhengle@263.net (Z.C.)
}

check for updates

Citation: Huo, H.; Zhang, D.; Chen, Z.; Di, Y.; He, X.; Li, N.; Hu, B. Geochemistry and Zircon U-Pb Geochronology of the Zhuxi Granites in the Jingdezhen Area, Jiangxi Province, China: Implications for the Mesozoic Tectonic Development of South China. Minerals 2022, 12, 283. https://doi.org/10.3390/ $\min 12030283$

Academic Editors: Hafiz U. Rehman, Atsushi Kamei, Clemente Recio and Yaoling Niu

Received: 13 January 2022

Accepted: 15 February 2022

Published: 24 February 2022

Publisher's Note: MDPI stays neutral with regard to jurisdictional claims in published maps and institutional affiliations.

Copyright: (C) 2022 by the authors. Licensee MDPI, Basel, Switzerland. This article is an open access article distributed under the terms and conditions of the Creative Commons Attribution (CC BY) license (https:// creativecommons.org/licenses/by/ $4.0 /)$.

\begin{abstract}
Mesozoic granitic magmatism in Northeastern Jiangxi, China is of tectonic significance for the evolution of the South China Block. Whole-rock geochemical and zircon U-Pb geochronological and Lu-Hf isotopic data for Mesozoic Zhuxi granites in the Jingdezhen area of Northeastern Jiangxi were presented. The Zhuxi granites are composed of granodiorite, biotite granite, and two-mica granite. Zircon LA-ICP-MS U-Pb isotopic analyses indicated emplacement at 159-147 Ma. The granites are characterized by a strongly peraluminous nature with high $\mathrm{A} / \mathrm{CNK}$ values $(>1.1)$, high $\mathrm{SiO}_{2}\left(66.09-74.46\right.$ wt.\%) and $\mathrm{K}_{2} \mathrm{O}(3.50-5.52$ wt.\%) contents, depletion in $\mathrm{Ba}, \mathrm{Nb}, \mathrm{Ce}$, $\mathrm{Sr}$, and $\mathrm{Ti}$, moderately negative $\mathrm{Eu}$ anomalies $\left(\mathrm{Eu} / \mathrm{Eu}^{*}=0.40-0.63\right)$, enrichment in LREE, and depletion in HREE $\left((\mathrm{La} / \mathrm{Yb})_{\mathrm{N}}>7.43\right)$. The A/CNK $>1.1$, widespread aluminum-rich minerals (e.g., muscovite and tourmaline), indicating they are S-type granites and belong to muscovite-bearing peraluminous granites (MPG). The Zhuxi granites exhibited negative $\varepsilon \mathrm{Hf}(t)$ values $(-9.9$ to -3.7$)$ and the $\mathrm{T}_{\mathrm{DM} 2}$ model ages of 1840-1442 Ma indicated derivation from ancient crustal sources. The magma is possibly caused by the subsequent process of intracontinental subduction. It is inferred that the Mesozoic magmatism in Northeastern Jiangxi was associated with oceanic-continental convergence of the Paleo-Pacific and Eurasian plates as well as the intracontinental subduction of the Yangtze and Cathaysia blocks. The Zhuxi granites highlight the primary role of oceanic-continental convergence and intracontinental subduction in early Yanshanian granitoid magmatism in South China.
\end{abstract}

Keywords: peraluminous S-type granite; zircon U-Pb geochronology; Hf isotopes; Zhuxi granites; Mesozoic; South China

\section{Introduction}

The South China Block (SCB) comprises the Yangtze Block to the north and Cathaysia Block to the south, which amalgamated during the Neoproterozoic after a collision along the Jiangnan orogenic belt (Figure 1a) [1-8]. There are widespread exposures of Mesozoic granitic magmatism in southern China [9-14]. Igneous processes and their relationships with the tectonic development of southeastern China are debated [4,5,8,12,15-21]. Geochronological and geochemical studies have generally linked Mesozoic magmatic evolution with the tectonic evolution of southern China. Intense magmatic activity in the region occurred mainly during the Jurassic (180-142 Ma) and Cretaceous (142-67 Ma) [22]. Mesozoic magmatic processes in southern China have been well documented concerning isotopic ages and geochemistry [23-27]. As an important junction of the Yangtze and Cathaysia blocks, Northeastern Jiangxi provides a window for the study of intracontinental 
subduction of the SCB and magmatic-tectonic processes in the region, contributing to our understanding of the evolution of the entire SCB (Figure 1b) [11,19,28-33].

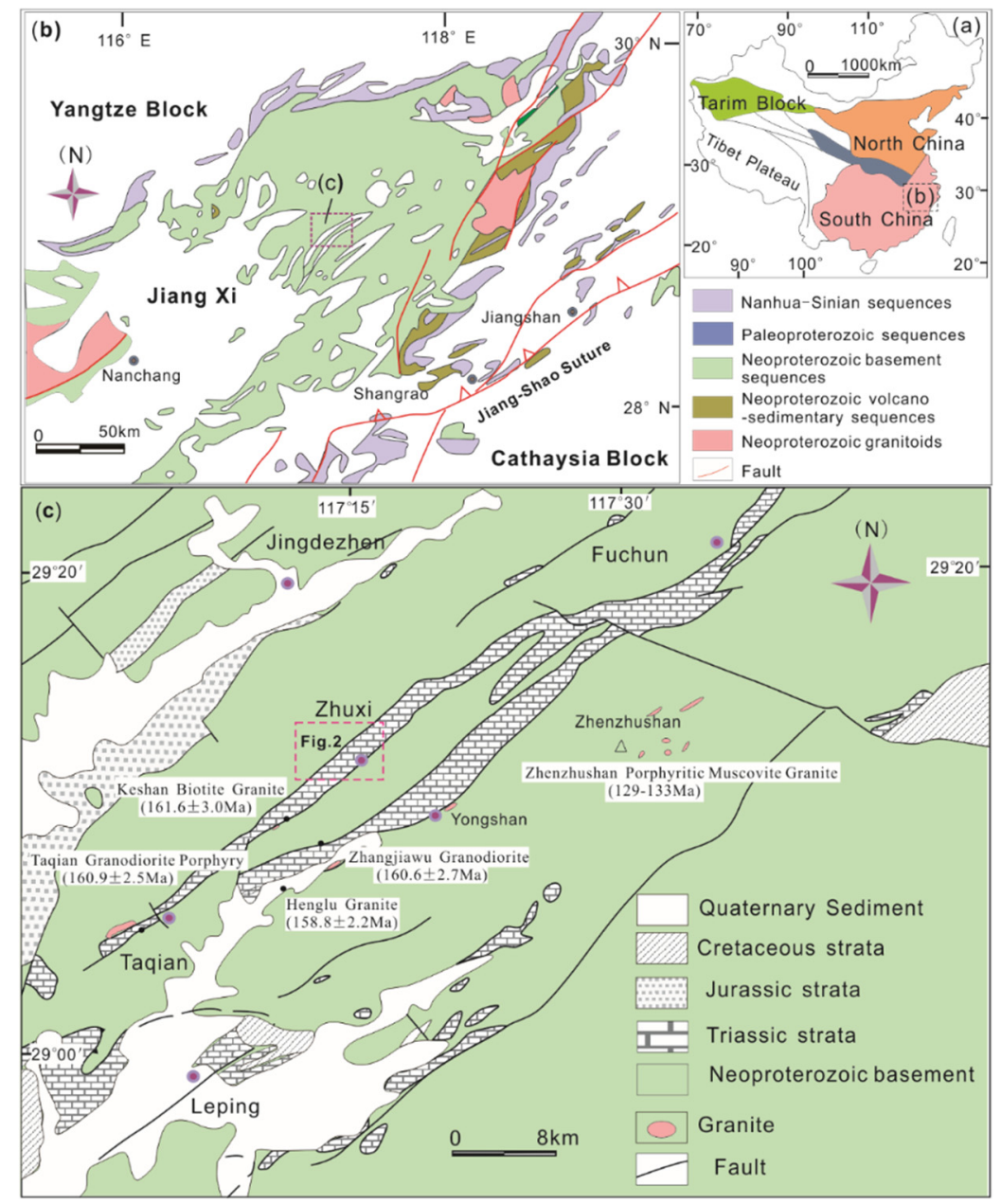

Figure 1. Geological map of the Jingdezhen area of the South China Block. (a) Inset shows the location of the South China Block. (b) Sketch tectonic map of the Jingdezhen and adjacent areas (modified from [34]). (c) Geological map of the Zhuxi area (modified from the [35]).

The present study focused on plutons in the Jingdezhen area of Northeastern Jiangxi, South China (Figure 1c). There are insufficient outcrops of igneous rocks to effectively constrain magmatic and tectonic processes in the Northeastern Jiangxi region. The Neoproterozoic, metamorphosed, sedimentary Shuangqiaoshan Group and coeval basins outcrop over most of the area, with boreholes having shown that the subcrop plutons are widespread (Figure 2a) [36-40]. The recently discovered Zhuxi granites are important in terms of the magmatic and tectonic evolution of the area. Detailed geological studies have focused on the geochronology, geochemistry, and isotopic characteristics of the Zhuxi granites (Figure 2b) [29,38,41-44]. Zircon LA-ICP-MS U-Pb geochronological studies have shown that the Zhuxi granites were formed primarily during the Late Jurassic (152-147 Ma) [29,38,41-44]. Although these studies provide insights into the Yanshanian granitoid evolution of the Zhuxi area, systematic analysis of the magmatic evolution and age relationships of granites in the Zhuxi area is limited. There is also a lack of comprehensive discussion on the Yanshanian tectonic-magmatic evolution process of Northeastern Jiangxi, South China. 


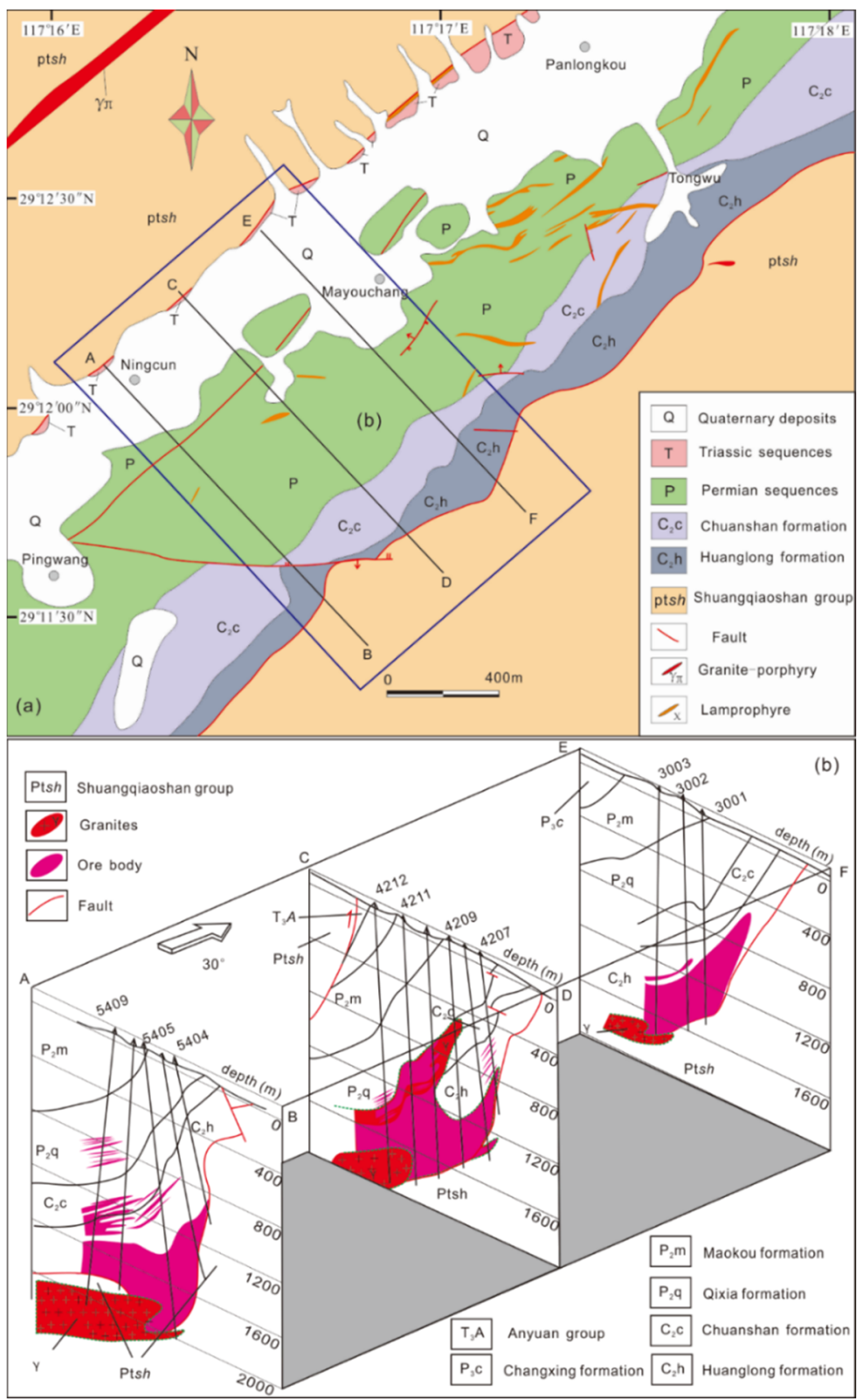

Figure 2. Simplified structural map of Jingdezhen showing (a) sample and stratigraphic section locations of this study, and (b) a 42-line stratigraphic section of the Zhuxi area.

Here we reported zircon $\mathrm{U}-\mathrm{Pb}$ geochronological and in-situ Hf isotopic data, and whole-rock major- and trace-element data for the Zhuxi granites in the Jingdezhen area. The data provide reliable constraints on regional magmatic and tectonic processes, help to elucidate relationships between tectonic evolution and magmatism, and provide additional information concerning the crustal evolution of South China.

\section{Geological Setting}

Northeastern Jiangxi is located in the southern Yangtze Block in the eastern part of the Jiangnan Orogenic Belt. The main stratigraphic units exposed in Northeastern Jiangxi and adjacent areas can be divided into weakly metamorphosed sandstone-siltstone Neoproterozoic basement, Paleozoic-Mesozoic shallow-marine carbonate and clasticsedimentary cover, and Neoproterozoic and Yanshanian granites (Figure 1a,b).

Neoproterozoic basement units of the Jiangnan Orogenic Belt in Northeastern Jiangxi are known as the Shuangqiaoshan Group (Figure 1b,c) [30,34,45-48]. This group is subdi- 
vided into the Hengyong, Jilin, Anlelin, and Xiushui formations (from oldest to youngest), which are dominated by metamorphic sandstone-siltstone, phyllite, slate, and pyroclastic rock intercalations $[35,46]$. The Shuangqiaoshan Group is the dominant folded basement strata in the eastern Jiangnan orogen, and is exposed mainly in the northwestern, northern, and northeastern parts of Jiangxi Province (Figure 1b) [14]. It is mainly composed of a thick pile (2678-5472 m) of pelitic and sandy sedimentary rocks with lesser volcanic rocks [14,48]. Zircon $\mathrm{U}-\mathrm{Pb}$ age data indicate that the Shuangqiaoshan Group formed during the Neoproterozoic (840-810 Ma; [14,30,32,34,45,49,50]). Neoproterozoic granites include the Jiuling pluton in NW Jiangxi and the Xucun, Shexian, and Xiuning plutons in southern Anhu. Previous studies have shown that these are strongly peraluminous S-type granites that were emplaced at 850-800 Ma (Figure 1b) [51-54].

Carboniferous to Cretaceous sedimentary cover is dominated by shallow-marine carbonate strata and clastic rocks. Structural studies of Northeastern Jiangxi and adjacent areas indicate that the eastern Jiangnan Orogenic Belt is dominated by NW-SE trending thrust faults, NW-vergent folds, and foliations [55]. The fold-and-thrust belt is characterized by multifold duplexes and individual folds, with the Neoproterozoic Shuangqiaoshan Group being thrust over Carboniferous to Triassic sedimentary strata [28,29].

The Yanshan orogenic belt is a typical continental orogenic belt of the Yanshanian age (Jurassic to Cretaceous period) [56]. The Yanshanian movement was an important intercontinental tectonic event and metallogenic period in China and was characterized by extensive magmatic activity and mineralization [56]. Yanshanian granites are the main igneous rock in the area and commonly occur along fault zones [28]. The few intrusions exposed in the study area include the Yangcaojian biotite granodiorite porphyry, the Zhangjiawu granodiorite porphyry, the Maojiayuan granodiorite, and the Zhenzhushan granite, and the NE-SW trending granite dyke as well as the minor lamprophyre dikes (Figure 2b) [28,38].

Recent studies have revealed voluminous subcrop intrusions in the study area, with zircon $\mathrm{U}-\mathrm{Pb}$ dating indicating that these plutons were formed mainly at 150-140 Ma [28,29,38,41-43].

\section{Analytical Methods}

\subsection{LA-ICP-MS U-Pb Zircon Dating}

In the present study, samples were collected near the Zhuxi village, $14 \mathrm{~km}$ southeast of Jingdezhen City (Figure 2a). Borehole Zk4212 in the Zhuxi granites was selected for detailed LA-ICP-MS zircon U-Pb chronological study, geochemical analyses, and in situ Hf isotopic analyses, with samples taken from different depths. The simplified sample descriptions, mineral assemblages, sampling location, and age of the representative Zhuxi granitoid rocks, Northeast Jiangxi Province are presented in Supplementary Table S1.

Three representative fresh samples from subcrop granitic plutons intruding the Shuangqiaoshan Group were selected for LA-ICP-MS U-Pb zircon dating. Zircon grains were extracted from the crushed whole-rock samples ZK4212-289, Tw13, and ZK4212-582, using standard density and magnetic separation techniques at the Diyuan Mineral Separating Limited, Hebei Province, China. Zircons were handpicked under a binocular microscope, mounted in epoxy resin, polished, and photographed in transmitted and reflected light. Cathodoluminescence (CL) images of the zircons were produced at Gaonian Navigation Technology Limited, Beijing, China, and sites for LA-ICP-MS analysis was based on these. LA-ICP-MS U-Pb zircon analyses were conducted at the Tianjin Institute of Geology and Mineral Resources (TIGMR), Tianjin, China. Laser sampling was performed using a New Wave UP $193 \mathrm{~nm}$ ArF excimer laser. A Thermofisher Neptune ICP-MS instrument was used to acquire ion-signal intensities. The laser-ablation spots were focused to $30 \mu \mathrm{m}$ diameter. NIST 610 glass and 91,500 zircon standards were used for calibration. Data processing was undertaken using Ludwig SQUID 1.03 and ISOPLOT 3.0 software [57]. The common $\mathrm{Pb}$ correction relied on assumed common $\mathrm{Pb}$ compositions (Stacey and Kramers model) [58]. Uncertainties for individual analyses are presented here 
as $\pm 1 \sigma$, and the weighted-mean age confidence level is $95 \%$. $\mathrm{U}$, Th, and $\mathrm{Pb}$ ratios are presented in Supplementary Table S2.

\subsection{Major-and Trace-Element Analyses}

Whole-rock major- and trace-element compositions were determined at the Institute of Geophysical and Geochemical Exploration (IGGE), Hebei Province, China. Major-element compositions were determined using a Philips X-ray fluorescence spectrometer (XRF; PW4400). Analytical precision was better than $\pm 5 \%$. Trace elements were analyzed using a Thermofisher ICAP Qc ICP-MS at Institute of Geophysical and Geochemical Exploration, Chinese Academy of Geological Sciences, Beijing, China (IGGE), using procedures similar to those described by [59]. Fresh borehole samples were pulverized to 200-mesh size, and powder aliquots $(\sim 50 \mathrm{mg})$ were heated in high-pressure Teflon beakers with an $\mathrm{HF}-\mathrm{HNO}_{3}$ mixture until the powder had completely dissolved. The solution was evaporated to dryness and the residue re-dissolved in $5 \% \mathrm{HNO}_{3}$ for elemental analysis. The results are listed in Supplementary Tables S3 and S4.

\subsection{Zircon Hf Isotopic Analyses}

Zircon in situ Hf isotopic analyses were carried out with a Neptune multi-collector ICP-MS coupled to a New Wave $193 \mathrm{~nm}$ FX laser-ablation system at Tianjin Institute of Geology and Mineral Resources (TIGMR), using a $50 \mu \mathrm{m}$ diameter laser beam and a $6 \mathrm{~Hz}$ repetition rate. The $\mathrm{Hf}$ isotope spots were targeted at the same domains as $\mathrm{U}-\mathrm{Pb}$ age determinations. The instrumental conditions and data acquisition procedures were described by [60]. Standard zircon GJ-1 was used as an unknown sample for qualitycontrol purposes, and gave a weighted mean ${ }^{176} \mathrm{Hf} /{ }^{177} \mathrm{Hf}$ ratio of $0.282006 \pm 0.000024(2 \sigma)$, consistent with the published value of $0.282008 \pm 0.000012$ [60].

\section{Petrography}

The Zhuxi granites are located in southeastern Jingdezhen and consist of granodiorite, biotite granite, two-mica granite (this study), leucocratic granite, and granite porphyry (Supplementary Table S1) [38,42]. The granodiorite (sample Zk4212-289) is a white, coarsegrained, leucocratic igneous rock comprising plagioclase (40-45 wt.\%), alkali feldspar (15-20 wt.\%), and quartz (15-20 wt.\%), with subordinate biotite (10-15 wt.\%) and muscovite (5-10\% wt.\%). In the hand-specimen, the plagioclase is white and lath-shaped, and the quartz is colorless and anhedral. Under cross-polarized light, the plagioclase is turbid owing to alteration, and quartz infills between plagioclase and alkali feldspar (Figure 3a,b). The biotite granite (sample Tw-13) is composed of plagioclase (25\%-35\%), alkali feldspar $(15 \%-20 \%)$, quartz $(45 \%-55 \%)$, and biotite $(5 \%-10 \%)$, and accessory minerals (e.g., zircon, apatite, titanite, and Fe-Ti oxides) (Figure 3c,d). The two-mica granite (sample Zk4212-582) is a white, coarse-grained, leucocratic igneous rock comprising quartz (30-35 wt.\%), alkali feldspar (20-25 wt.\%), and plagioclase (35-40 wt.\%), with subordinate biotite (5-10 wt.\%) and muscovite (15-20 wt.\%). Under cross-polarized light, the plagioclase is partly replaced by clay minerals, and the quartz is clear and unaltered (Figure 3e,f). Fine-grained muscovite granite is mainly composed of quartz, microcline, plagioclase, muscovite, and minor accessory minerals (e.g., zircon, apatite, monazite, ilmenite). The representative Zhuxi granitoid rock locations, lithologies, mineral assemblages, and age results are summarized in Supplementary Table S2. 


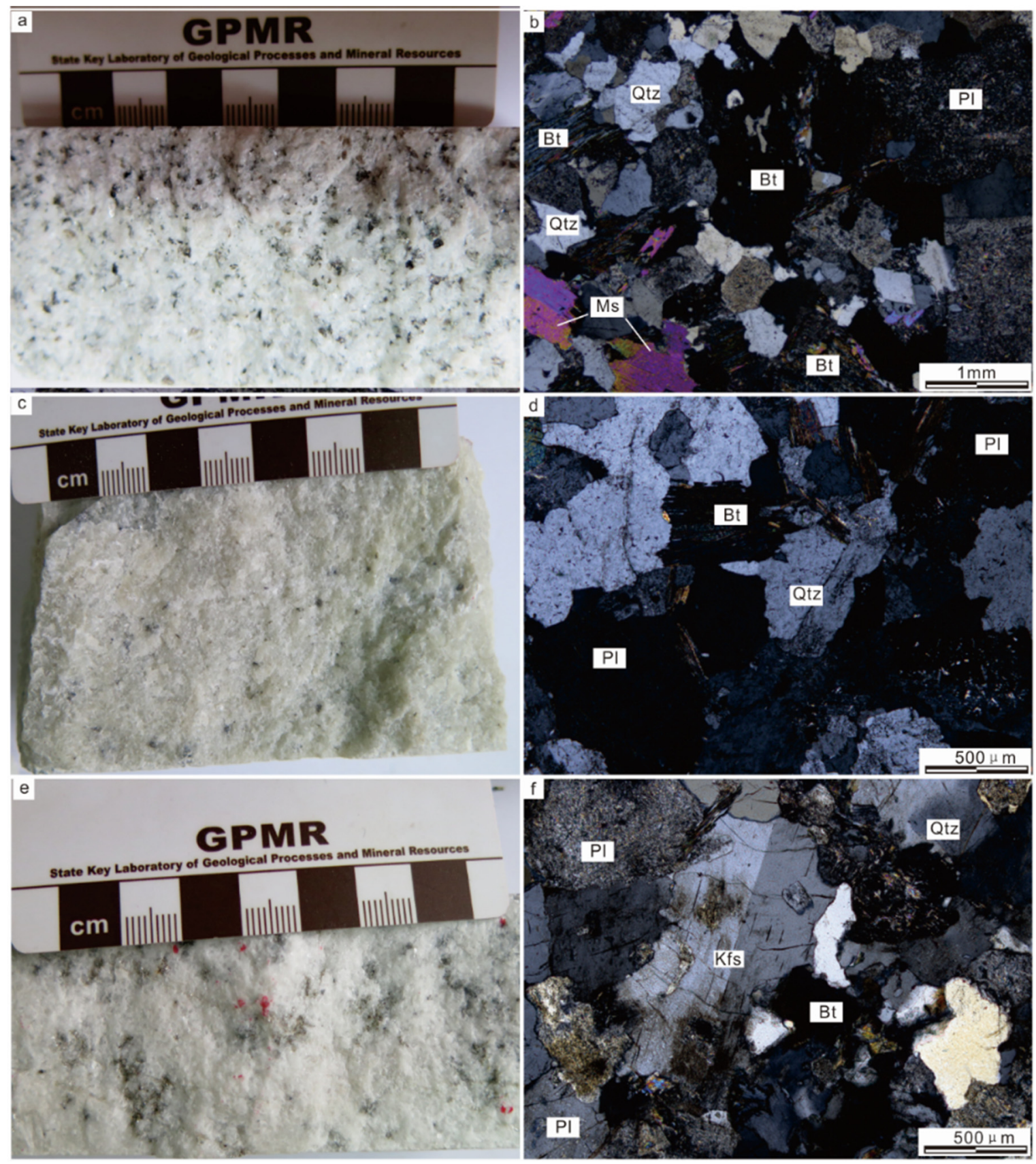

Figure 3. Hand specimen views and photomicrographs of granites in the Jingdezhen area: $(\mathbf{a}, \mathbf{b})$ twomica granite; (c,d) biotite granite; (e,f) granodiorite. Abbreviations: Qtz—quartz; Bt—biotite; Msmuscovite; Pl—plagioclase; Kfs-Kfeldspar.

\section{Geochronology and Hf Isotopic Compositions}

Representative granodiorite (Zk4212-289), biotite granite (Tw13), and two-mica granite (Zk4212-582) samples were collected for zircon U-Pb dating. Separated zircons have mostly euhedral shapes, are 40-250 $\mu \mathrm{m}$ long, and exhibit strong oscillatory zoning, typical of a magmatic origin. Analytical results for $\mathrm{U}-\mathrm{Pb}$ and $\mathrm{Lu}-\mathrm{Hf}$ isotopic compositions are listed in Supplementary Tables S2 and S5. In situ Lu-Hf analyses were performed on ablation spots previously analyzed for $\mathrm{U}-\mathrm{Pb}$ isotopes.

Zircons with oscillatory zoning from samples Zk4212-289, Tw13, and Zk4212-582 were selected for ${ }^{206} \mathrm{~Pb} /{ }^{238} \mathrm{U}$ dating (Figure 4). For sample Zk4212-289, 27 ablation spots gave concordant results (within error), with a weighted-mean age of $159 \pm 1 \mathrm{Ma}(\mathrm{MSWD}=2.10)$ 
(Figure 4a,b); 11 analyses of Tw13 yielded a weighted mean age of $147 \pm 2 \mathrm{Ma}(\mathrm{MSWD}=4.80$ ), with a further seven showing older ages and interpreted as being xenocrysts (Figure 4c,e); 19 analyses of Zk4212-582 yielded a weighted mean age of $147 \pm 1 \mathrm{Ma}(\mathrm{MSWD}=2.00$ ) (Figure 4e,f).
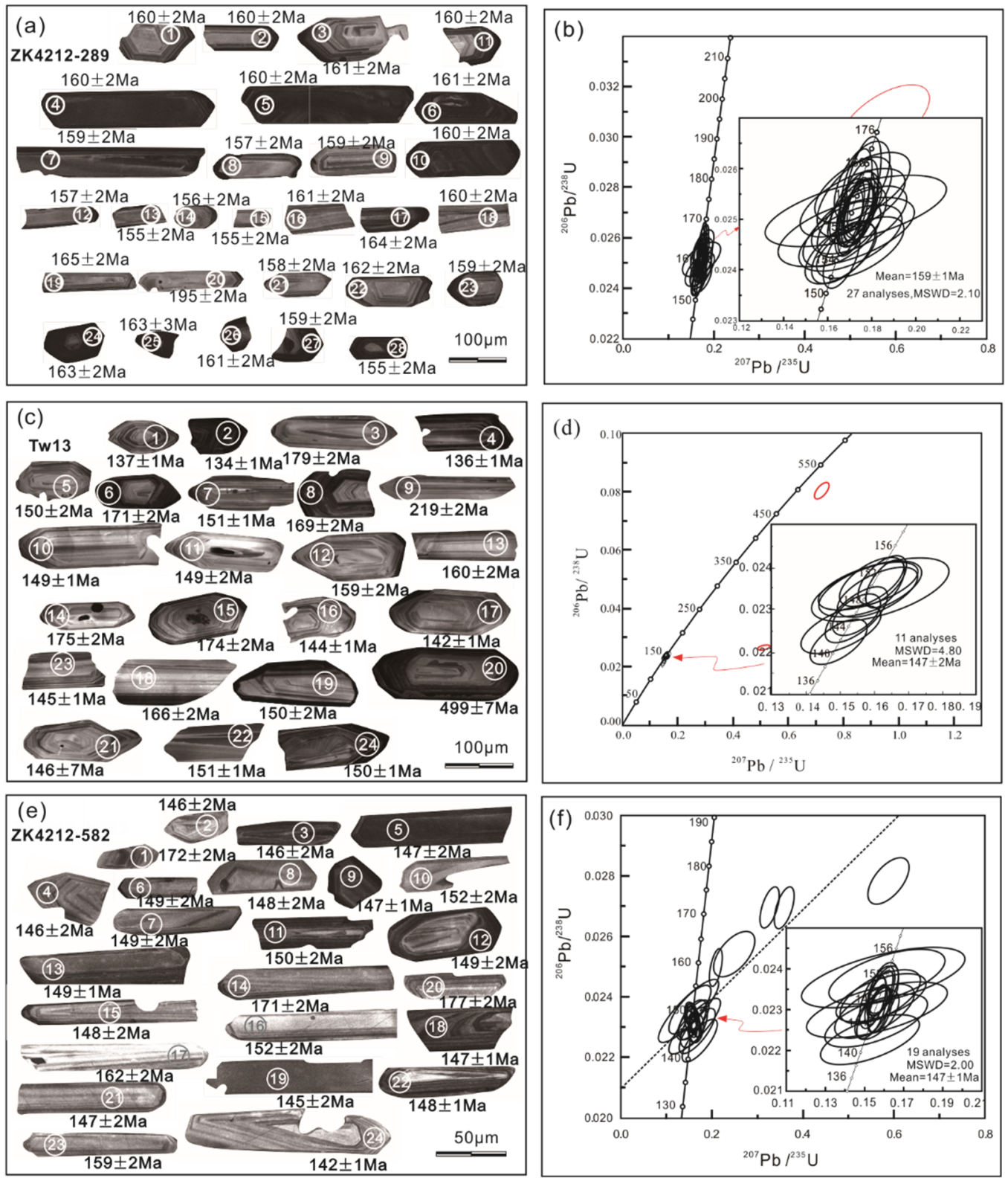

Figure 4. CL images, analytical sites, spot ages, and U-Pb Concordia diagram for Zhuxi granites in the Jingdezhen area; granodiorite Zk4212-289 (a,b), biotite granite Tw13 (c,d) two-mica granite Zk4212-582 (e,f).

For sample $\mathrm{Zk} 4212-289,12 \mathrm{Hf}$ isotopic analyses gave $\varepsilon \mathrm{Hf}(t)$ values of -9.9 to -5.8 and two-stage model $\left(\mathrm{T}_{\mathrm{DM} 2}\right)$ ages of $1840-1577 \mathrm{Ma}$, with initial ${ }^{176} \mathrm{Hf} /{ }^{177} \mathrm{Hf}$ ratios of $0.008188-0.037726 ; 15$ analyses of Tw13 gave $\varepsilon \mathrm{Hf}(t)$ values of -9.2 to -3.7 and TDM2 ages of $1802-1442 \mathrm{Ma}$, with initial ${ }^{176} \mathrm{Hf} /{ }^{177} \mathrm{Hf}$ ratios of $0.008303-0.050235 ; 12$ analyses of Zk4212-582 gave $\varepsilon H f(t)$ values of -8.9 to -4.9 and $\mathrm{T}_{\mathrm{DM} 2}$ ages of $1765-1512 \mathrm{Ma}$, with initial ${ }^{176} \mathrm{Hf} /{ }^{177} \mathrm{Hf}$ ratios of $0.012093-0.031711$. 


\section{Geochemistry}

Major- and trace-element compositions of 12 granites are listed in Supplementary Tables S3 and S4. Most samples had low loss-on-ignition (LOI) values, except the granodiorites (samples H285, H289, and H307) for which higher values might be due to oxidation. As a comparison, geochemical analysis was also conducted for the base strata Shuangqiaoshan group. The sampling locations and major element contents are shown in [30], and the trace elements are listed in Supplementary Table S4.

The granodiorite samples were characterized by $66.09-74.46 \mathrm{wt} . \% \mathrm{SiO}_{2}, 0.06-0.24 \mathrm{wt} . \%$ $\mathrm{Na}_{2} \mathrm{O}, 3.50-4.62$ wt. \% $\mathrm{K}_{2} \mathrm{O}, 0.26-0.40$ wt.\% MgO, 2.51-4.22 wt.\% CaO, 13.12-18.45 wt.\% $\mathrm{Al}_{2} \mathrm{O}_{3}$, and $0.09-0.16$ wt. $\% \mathrm{TiO}_{2}$, respectively. A total alkali-silica (TAS) diagram showed that the samples plot in the granodiorite fields (except one plot in granite field) (Figure 5a). Most had high $\mathrm{K}_{2} \mathrm{O} / \mathrm{Na}_{2} \mathrm{O}$ ratios, and plot in the high- $\mathrm{K}$ calc-alkaline field in the $\mathrm{K}_{2} \mathrm{O}-\mathrm{SiO}_{2}$ diagram (Figure 5b). The samples were peraluminous, with A/CNK values of 1.20-2.30, ALK (total alkali $\left(\mathrm{Na}_{2} \mathrm{O}+\mathrm{K}_{2} \mathrm{O}\right)$ ) contents 3.59-4.86 wt.\%, and A/NK values of 3.34-3.47 (Figure 5c).
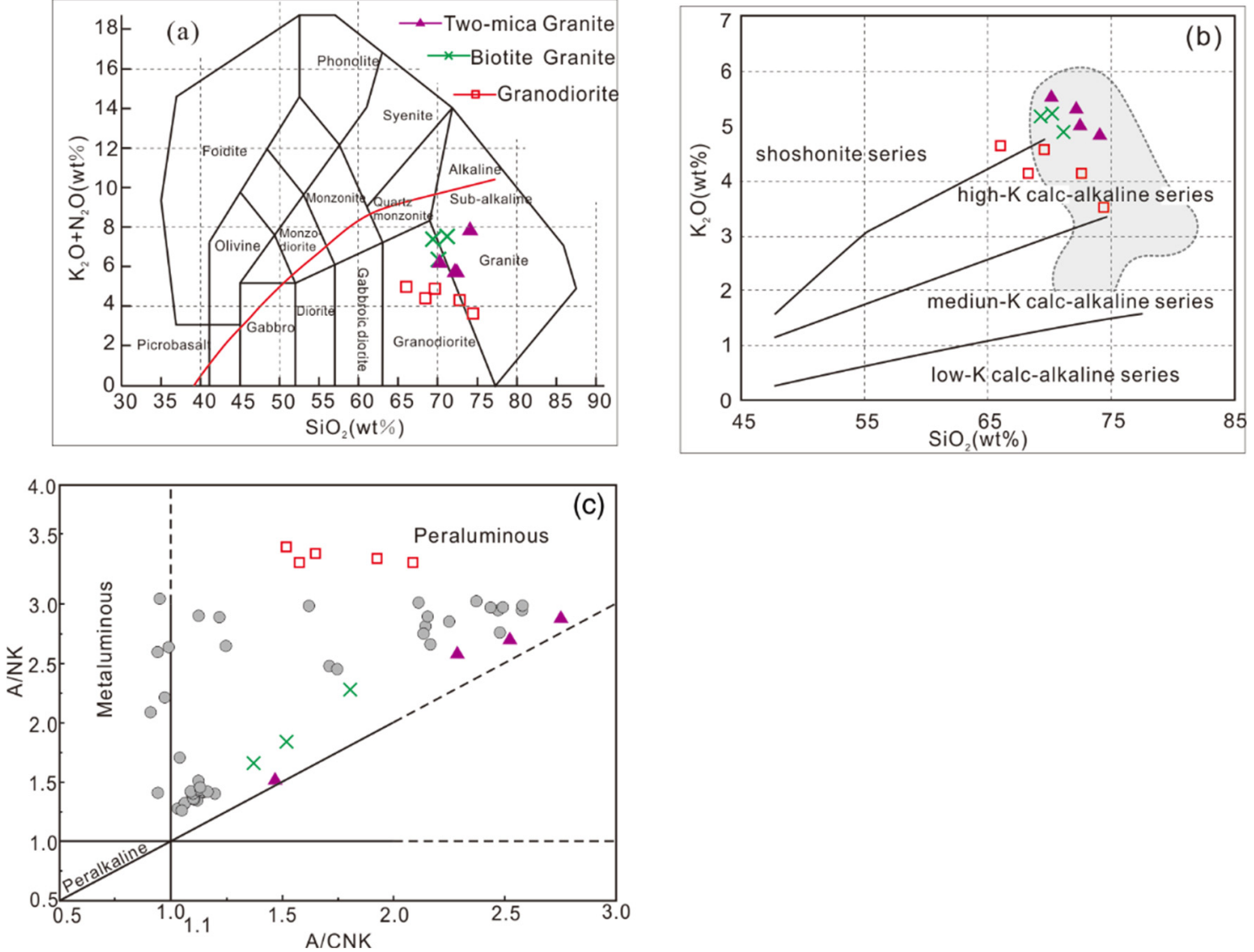

Figure 5. (a) Total alkali-silica (TAS) diagram (after [61,62]; (b) $\mathrm{K}_{2} \mathrm{O}-\mathrm{SiO}_{2}$ diagram (after [63]) and (c) A/NK-A/CNK diagram (after [64]) for the Zhuxi granites from the Jingdezhen area. The shaded area in (b) and circles in (c) denote published data for the Zhuxi granites [38,42,43].

The biotite granite samples were characterized by $69.37-71.12$ wt. $\% \mathrm{SiO}_{2}$, 0.90-2.35 wt.\% $\mathrm{Na}_{2} \mathrm{O}, 4.86-5.18$ wt.\% $\mathrm{K}_{2} \mathrm{O}, 0.37-0.41$ wt.\% $\mathrm{MgO}, 1.83-1.90$ wt.\% $\mathrm{CaO}$, 15.08-16.10 wt.\% $\mathrm{Al}_{2} \mathrm{O}_{3}$, and 0.26-0.276 wt.\% $\mathrm{TiO}_{2}$, respectively. A total alkali-silica (TAS) diagram showed that the samples plot in the boundary field of granodiorite and granite (Figure 5a). Most had high $\mathrm{K}_{2} \mathrm{O} / \mathrm{NaO}$ ratios, and plot in the shoshonite field in the $\mathrm{K}_{2} \mathrm{O}-\mathrm{SiO}_{2}$ diagram (Figure $5 \mathrm{~b}$ ). The samples were peraluminous, with $\mathrm{A} / \mathrm{CNK}$ values of 1.20-1.55, ALK contents 6.08-7.21 wt.\%, and A/NK values of 1.65-2.27 (Figure 5c). 
The two-mica granite samples were characterized by $70.33-74.22$ wt.\% $\mathrm{SiO}_{2}$, 0.22-2.69 wt.\% $\mathrm{Na}_{2} \mathrm{O}, 4.84-5.52$ wt.\% $\mathrm{K}_{2} \mathrm{O}, 0.13-0.26$ wt.\% $\mathrm{MgO}, 0.85-1.26$ wt.\% $\mathrm{CaO}$, 14.52-17.62 wt. $\% \mathrm{Al}_{2} \mathrm{O}_{3}$, and $0.09-0.15$ wt. $\% \mathrm{TiO}_{2}$, respectively. A total alkali-silica (TAS) diagram showed that the samples plot in the boundary field of granodiorite and granite (Figure 5a). Most had high $\mathrm{K}_{2} \mathrm{O} / \mathrm{NaO}$ ratios, and plot in high- $\mathrm{K}$ calc-alkaline and shoshonite fields in the $\mathrm{K}_{2} \mathrm{O}-\mathrm{SiO}_{2}$ diagram (Figure $5 \mathrm{~b}$ ). The samples were peraluminous, with A/CNK values of 1.28-2.30, ALK contents 5.52-7.53 wt.\%, and A/NK values of 1.50-2.88 (Figure 5c).

The studied Zhuxi granite samples were characterized by relatively varied trace element compositions, the samples had total rare-earth element ( $\Sigma$ REE) contents of 46.09-173.30 ppm, and all granitic samples showed light REE (LREE) enrichment in the chondrite-normalized REE diagram (Figure 6a and Supplementary Table S4), which showed that with most $(\mathrm{La} / \mathrm{Yb})_{\mathrm{N}}$ values being greater than 7.43 (except samples H522 and H530) had negative $\mathrm{Eu}$ anomalies $\left(\mathrm{Eu} / \mathrm{Eu}^{*}=0.40-0.63\right)$ and showed a regular-changes degree of partial melting. In the N-MORB-normalized trace-element spider diagram (Figure $6 \mathrm{~b}$ ), the granites exhibited positive $\mathrm{Nd}, \mathrm{Hf}$, and $\mathrm{Sm}$ anomalies, and negative $\mathrm{Ba}, \mathrm{Nb}, \mathrm{Ce}, \mathrm{Sr}$, and $\mathrm{Ti}$ anomalies. Negative $\mathrm{Ba}$ and $\mathrm{Sr}$ anomalies may indicate residual accessory minerals from partial melting, while plagioclase fractional crystallization continued in the magma.
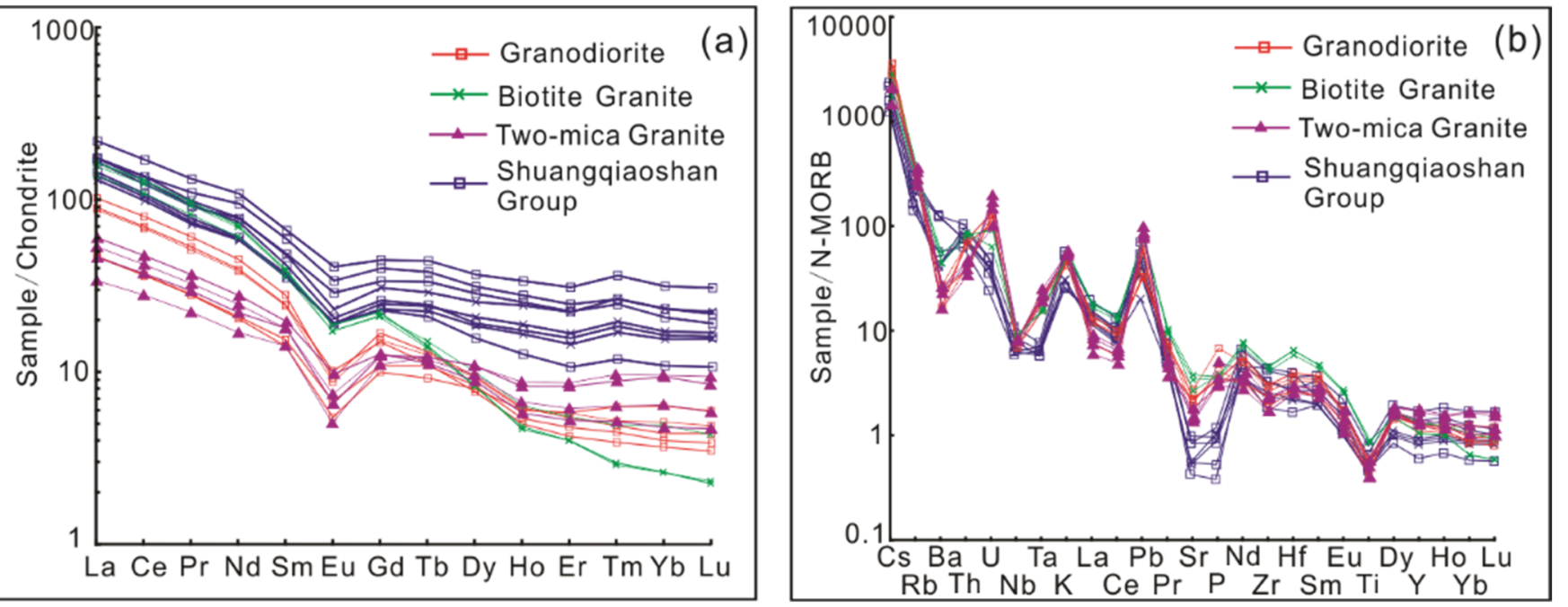

Figure 6. (a) Chondrite-normalized REE and (b) N-MORB-normalized trace-element spider patterns of the Zhuxi granites and Shuangqiaoshan Group (normalizing factors are from [65]; E-MORB, OIB, and N-MORB compositions are from [66]).

\section{Discussion}

\subsection{Petrogenesis}

\subsubsection{Petrogenetic Type: S-Type Affinity (MPG)}

Early Yanshanian igneous rocks are widespread in the eastern SCB, with most having formed during the Early-Late Early Yanshanian (180-160 Ma: mainly I-type granites; and 160-140 Ma: mainly S-type granites) [67,68]. Our zircon U-Pb data indicated the Zhuxi granites were formed at 159-147 Ma, which corresponds to the Early Yanshanian. The genetic classification of the Zhuxi granites in Northeastern Jiangxi is still controversial. They have been regarded as S-type granites [36,42,43], or as I-S transformation-type granites [37,69].

The Zhuxi granites are peraluminous, as indicated by their A/CNK ratios (1.20-2.30). In the $\mathrm{K}_{2} \mathrm{O}-\mathrm{SiO}_{2}$ discrimination diagram (Figure $5 \mathrm{~b}$ ), most samples plot in the high- $\mathrm{K}$ calc-alkaline and shoshonite fields, with $\mathrm{K}_{2} \mathrm{O}$ contents of 3.50-5.52 wt.\%. The Zhuxi granites are typical S-type granites rather than I-S transformation granites, as indicated by A/CNK > 1.1, muscovite granite, two-mica granite and biotite granite, and widespread aluminum-rich minerals (e.g., muscovite and tourmaline) [42,70-73]. Together with the 
lack of type minerals (e.g., cordierite and allanite), this indicates that the Zhuxi granites belong to muscovite-bearing peraluminous granites (MPG) [70].

\subsubsection{Sources Nature}

The combined evidence from geochemical and isotopic constraints and experimental petrology quite accept that the muscovite-bearing peraluminous granites (MPG) are granites of crustal origin and developed through partial melting of protoliths dominated by metasedimentary rocks [70-75].

The strongly negative Eu anomalies $\left(\mathrm{Eu} / \mathrm{Eu}^{*}=0.40-0.63\right)$, enrichment in LREEs, and depletion in HREEs of the Zhuxi granites are attributed to the feldspar fractionation or retention of feldspar in the source area (Figure 6a) [65]. In the MORB-normalized traceelement diagram (Figure 6b) [66], the obvious $\mathrm{Sr}$, Ti, and $\mathrm{Ba}$ negative anomalies likely result from extensive fractionation of plagioclase or K-feldspar, and the strong negative $\mathrm{Nb}$ anomaly may indicate that the parent magma is the crustal source [70]. The trace-element characteristics of the Zhuxi granites are consistent with those of samples from the lowmetamorphic clastic sedimentary strata, and the aluminum enrichment in magma was most likely derived from aluminum-rich metasedimentary protoliths (Figure $6 \mathrm{a}, \mathrm{b}$ ).

Most of the Zhuxi granites exhibited negative $\varepsilon \mathrm{Hf}(t)$ values of -9.9 to -3.7 and $\mathrm{T}_{\mathrm{DM} 2}$ ages of 1840-1442 Ma, which is older than the zircon $\mathrm{U}-\mathrm{Pb}$ ages (Supplementary Table S5 and Figure 7). This may indicate that the Zhuxi granites magma was derived from a crustal source [76,77]. The detailed petrography, geochronology, and geochemistry analysis of Shuangqiaoshan Group strata were published, indicating the Shuangqiaoshan Group were deposited at Neoproterozoic [30,34,78].
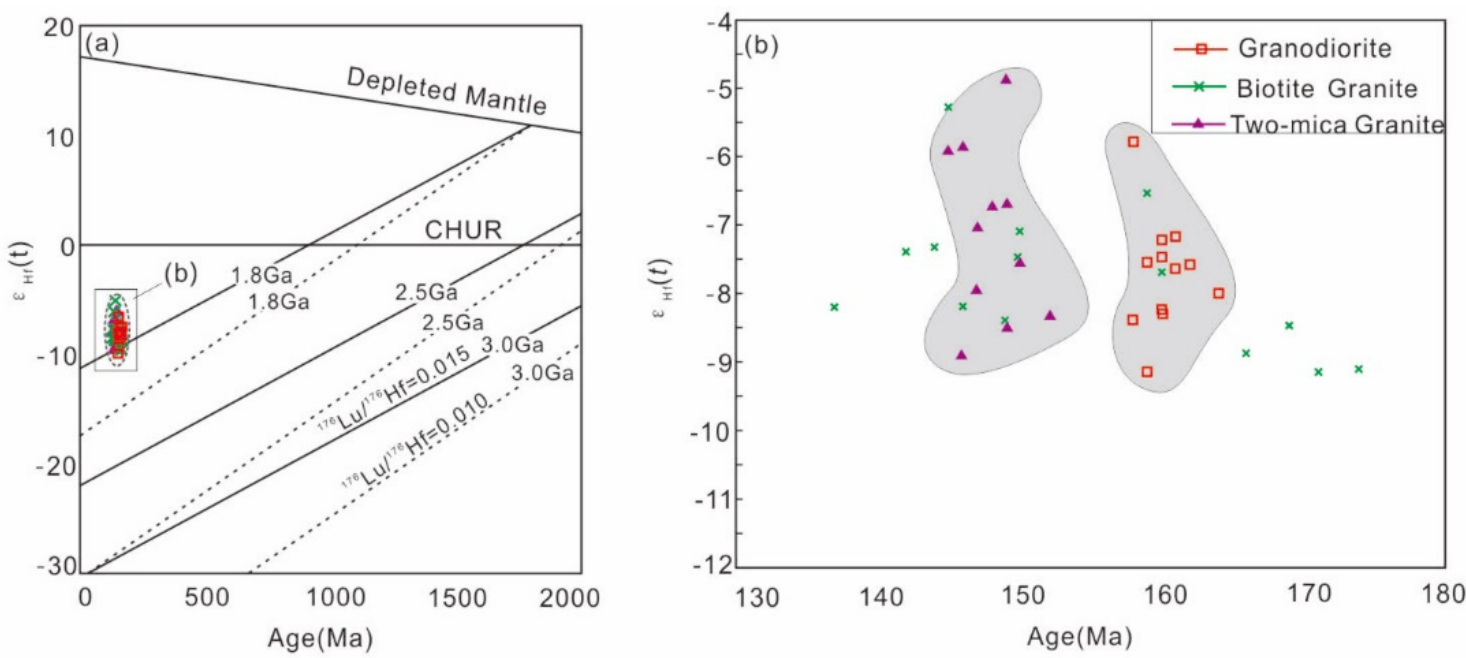

Figure 7. Plot of zircon $\varepsilon \mathrm{Hf}(t)$ vs. ${ }^{206} \mathrm{~Pb} /{ }^{238} \mathrm{U}$ ages (a), and variation $\mathrm{Hf}$ isotopic trend of the samples (b), for Zhuxi granites of the Jingdezhen area, indicating the intrusion formed by the reworking of middle-lower crust. The corresponding lines are after [79]. The shaded area denotes published data for the Zhuxi granites $[38,42,43]$.

The Zhuxi granites had relatively high $\mathrm{Rb} / \mathrm{Ba}$ and $\mathrm{Rb} / \mathrm{Sr}$ ratios, implying an affinity with pelite-derived melt, and all samples plot in the clay-rich field in the $\mathrm{Rb} / \mathrm{Ba} \mathrm{vs}$. $\mathrm{Rb} / \mathrm{Sr}$ diagram, indicating a plagioclase fractionation trend (Figure 8a) [80]. In the $\mathrm{CaO} / \mathrm{Na}_{2} \mathrm{O}-$ $\mathrm{Al}_{2} \mathrm{O}_{3} / \mathrm{TiO}_{2}$ diagram (Figure $8 \mathrm{~b}$ ), the $\mathrm{Zhuxi}$ granites displayed varied $\mathrm{CaO} / \mathrm{Na}_{2} \mathrm{O}$ ratios. Considering the $\mathrm{Na}_{2} \mathrm{O}$ have a negative relationship with LOI, the decrease of $\mathrm{Na}_{2} \mathrm{O}$ caused by alteration causes the increase of $\mathrm{CaO} / \mathrm{Na}_{2} \mathrm{O}$, so the spots should plot in the pelitederived melt field, further indicating magma was derived from partial melting of the pelite rocks. 


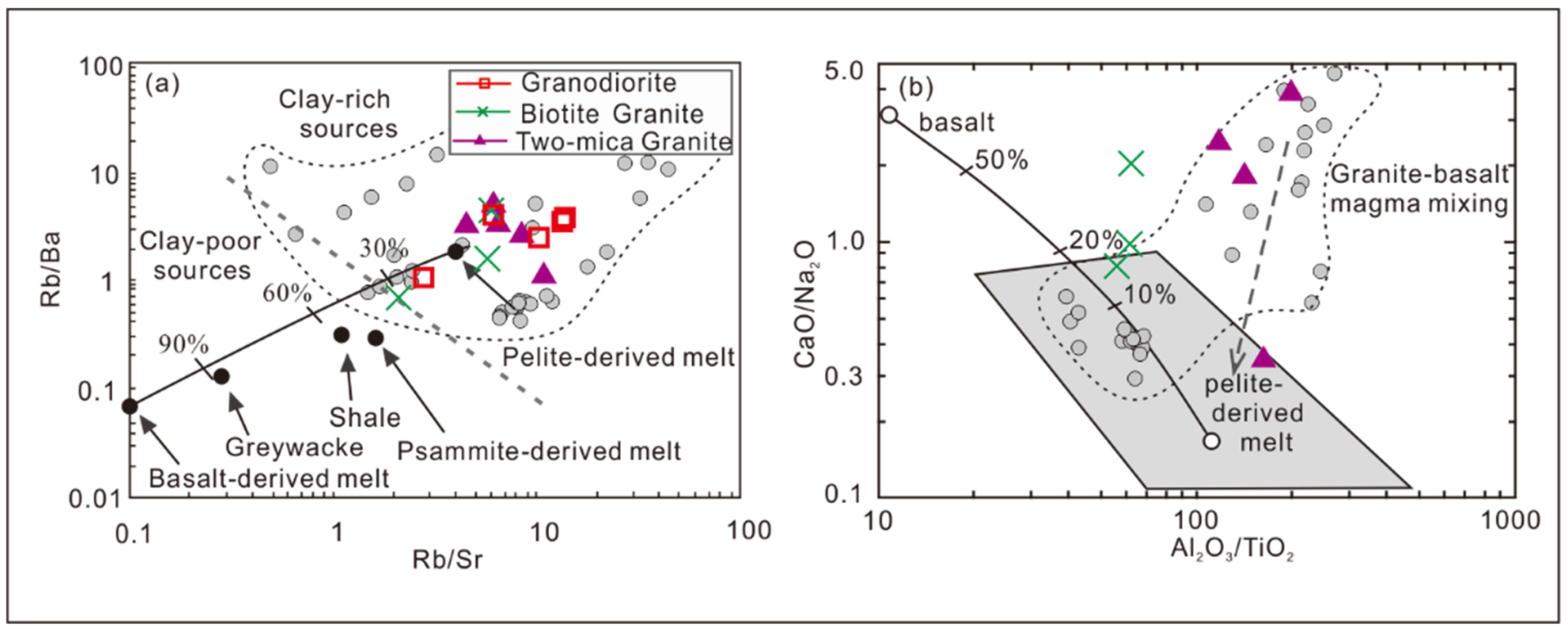

Figure 8. (a) $\mathrm{Rb} / \mathrm{Ba}-\mathrm{Rb} / \mathrm{Sr}[80]$ and (b) $\mathrm{CaO} / \mathrm{Na}_{2} \mathrm{O}-\mathrm{Al}_{2} \mathrm{O}_{3} / \mathrm{TiO}_{2}$ (after [80]; diagrams for the Zhuxi granites of the Jingdezhen area. The dashed line divides granitites derived mostly from clay-poor sources from those formed from clay-rich source rocks. The circles in the diagrams denote published data for the Zhuxi granites [38,42,43].

In the diagrams of Ba vs. Eu, Sr vs. Eu, Ba vs. Sr, and $(\mathrm{La} / \mathrm{Yb})_{\mathrm{N}}$ vs. La (Figure 9), the element variations indicated that plagioclase and $\mathrm{K}$-feldspar fractionation is required (Figure $9 \mathrm{a}-\mathrm{c}$ ). The fractionation of plagioclase can result in negative $\mathrm{Sr}$ and Eu anomalies and the fractionation of $\mathrm{K}$-feldspar led to negative $\mathrm{Ba}$ and Eu anomalies (Figure 6). In addition, the negative Ti anomalies of the Zhuxi granites (Figure 6) may indicate the fractionation of micas that occurred in magma evolution. Moreover, the abundant laterperiod fluorite veins were inconsistent with the fractionation of micas [36,73,81].

\subsection{Regional Magmatism of the Northeast Jiangxi and Adjacent Area}

The geochronology and geochemistry of the Zhuxi granites have been extensively studied (Supplementary Table S1; e.g., [29,38,41-43]. Li et al. [41] suggested that the crystallization ages of granite porphyry of the Zhuxi granites was 149 151 Ma, indicating a Late Jurassic magmatic event in Northeastern Jiangxi. Chen et al. [28,29] concluded that the 152-148 Ma age of medium- to coarse-grained granite and porphyry granites of the Zhuxi granites indicates they are a product of an early Yanshanian tectonic-magmatic event. Other studies also reported a 153-148 Ma age for the Zhuxi granites [38,43].

Zircon U-Pb ages of the Yanshanian granites along the Taqian-Fuchun fold-thrust belt (i.e., the Zhangjiawu granodiorite, Taqian biotite granite porphyry, Henglu granite, and Zhuxi two-mica granite) are 160.6 $\pm 2.7 \mathrm{Ma}, 161.6 \pm 3.0 \mathrm{Ma}, 158.8 \pm 2.2 \mathrm{Ma}$, and $148.6 \pm 1.3 \mathrm{Ma}$, respectively (Supplementary Table S1; [42]). Geochemical and isotopic characteristics indicate that these granites have similar origins and were formed during the same magmatic event at 160-145 Ma. 

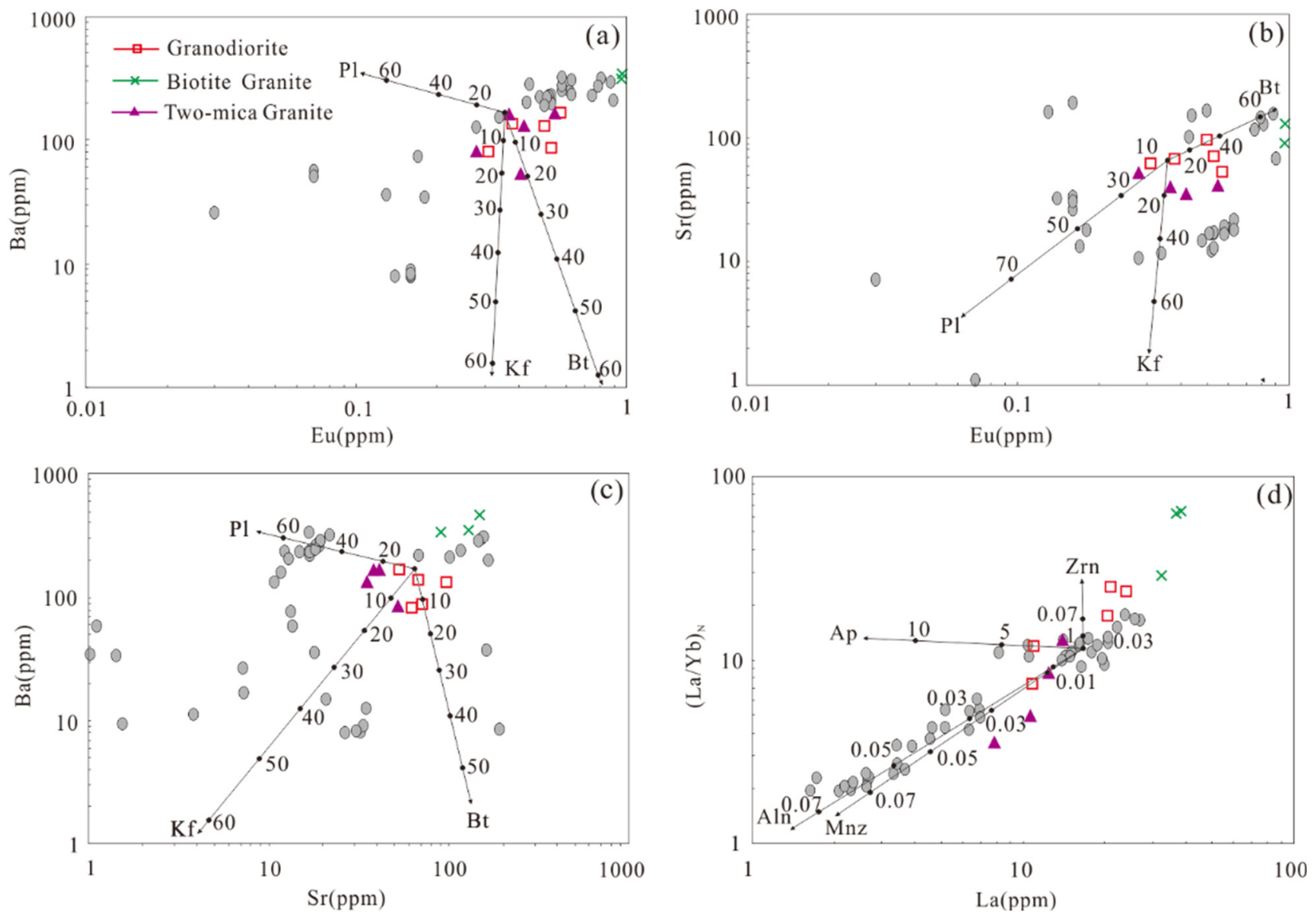

Figure 9. (a) Ba vs. Eu, (b) Sr vs. Eu, (c) Ba vs. Sr, and (d) $(\mathrm{La} / \mathrm{Yb})_{\mathrm{N}}$ vs. La diagrams of the Zhuxi granites. Partition coefficients of $\mathrm{Ba}$ and $\mathrm{Sr}$ are from [82], Eu is from [83], apatite is from [84], zircon and allanite are from [85], and monazite is from [86]. Abbreviations: Pl—plagioclase; Kf-K-feldspar; Bt—biotite; Aln—allanite; Mnz-monazite; Ap—apatite; Zrn—zircon.

Magmatic processes during the Yanshanian occurred during two main stages in the Zhuxi area. Granite that formed during the early stage is mainly granodiorite, whereas the late stage is dominated by two-mica granite and biotite granite $[28,29,38,42,43,87]$. Earlier studies focused mainly on the geochronology and geochemistry of the later granites, finding they were formed at 147-153 Ma, indicating a Late Jurassic stage of Yanshanian magmatism in the Zhuxi area $[29,38,41,43,88]$.

In the present study, the early-stage granodiorite yielded a zircon $\mathrm{U}-\mathrm{Pb}$ age of $159 \pm 1 \mathrm{Ma}$, and the late-stage two-mica granite and biotite granite yielded ages of $147 \pm 2$ and $147 \pm 1 \mathrm{Ma}$, respectively. The granodiorite age of $159 \pm 1 \mathrm{Ma}$ is consistent with the widespread Middle Jurassic magmatic rocks of the Zhuxi area [42,88,89]. The ages of the two-mica granites and biotite granites are consistent with those of previous studies and represent the second stage of Yanshanian magmatism. This indicates that magmatic processes in the Zhuxi granites proceeded for at least 10 Ma during the Middle-Late Jurassic. The pluton contained two sequences of granodiorite and two-mica biotite granite. Geochemical characteristics and isotopic data indicated that these granites display similar magma evolutionary trends, having undergone multi-stage magma evolution, and are the result of homologous magmatic differentiation [36,38,43]. Furthermore, the ages of lamprophyre veins in the Zhuxi area are $160 \mathrm{Ma}$ [88]. The zircon Hf isotopic composition of the lamprophyre indicates it was contaminated by crustal components, but the genetic relationship between the granites and the lamprophyre remains unclear $[88,90]$.

The Late Jurassic S-type muscovite (two-mica) granite is widespread in the interior of the SCB (e.g., the Jiufeng pluton in the Dahutang area, the Xukeng pluton in the Wugongshan area, and the Zhuxi granites in the Jingdezhen area; Supplementary Table S6); [38,43,74,91-93]. 
The peraluminous granites (MPG) are mainly emplaced where there is crustal thickening resulting from the convergence of two continental lithospheres [70]. Previous studies have suggested that these Yanshanian granites are closely related to an intercontinental collisional orogeny and are the products of the syn-collision or post-collision stages [94-96]. However, other studies have suggested that collision-related A-type granites were produced during the Indosinian and were likely associated with the Triassic collision between the North and South China blocks [97-99]. During the Yanshanian (Jurassic-Cretaceous), the SCB entered an intraplate deformation stage with widespread magmatism, without significant collisional orogeny [67,100-102]. As in the intracontinental subduction zone, magmas form during the convergence tectonics and are emplaced when there is tension or local relaxation along some shear zones [70].

Intracontinental subduction in South China caused large-scale thrust-nappe tectonics and induced partial melting of thickened crust, which produced the S-type muscovite (two-mica) granites. Geochemistry and Hf isotopic compositions also indicate that these S-type granites are the products of partial melting of ancient crustal material. They are widely dispersed and were formed over a long period, distinct from magmatism related to an orogenic event [5].

\subsection{Tectonic Implications}

The Mesozoic tectonic activity was intense in South China, with the transformation from the Meso-Tethyan tectonic domain to the Western Pacific domain causing intense intraplate orogenesis and magmatism [99,101,103-106]. Large-scale Mesozoic Yanshanian magmatism in the SCB is one important outcome of this transformation $[9,10,13,17,33,101]$.

In the Hf-(Rb/10)-(3Ta) tectonic discrimination diagram (Figure 10a; [107]), the Jingdezhen samples plot in the field of collisional granites (COLG), while in the Hf( $\mathrm{Rb} / 30)-(3 \mathrm{Ta})$ diagram (Figure 10b) the two-mica granites and granodiorites plot in the syn-collisional granitoid (S-COLG) field. The granodiorites also plot in the overlapping field of volcanic arc granitoid (VAG) and S-COLG. In $\mathrm{Rb}-(\mathrm{Yb}+\mathrm{Ta}), \mathrm{Rb}-(\mathrm{Y}+\mathrm{Nb})$, and $\mathrm{Ta}-\mathrm{Yb}$ tectonic discrimination diagrams, all the samples plot in the S-COLG field (Figure 11a,b,d). In the $\mathrm{Nb}-\mathrm{Y}$ discrimination diagram, the samples plot in the S-COLG and VAG fields (Figure 11c; [108]). In all these tectonic discrimination diagrams, most samples plot in the syn-collisional field and some plot in the collisional field (Figures 10 and 11).

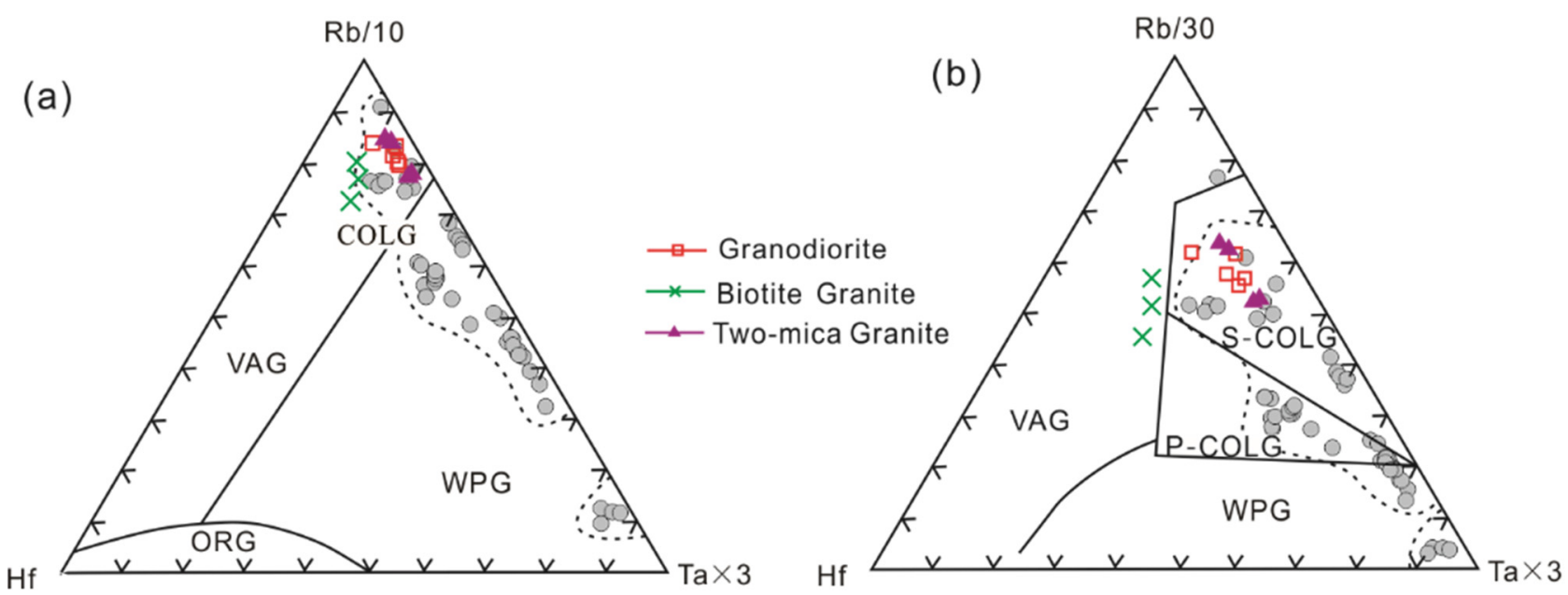

Figure 10. Tectonic discrimination diagrams for Zhuxi granites of the Jingdezhen area. (a) $\mathrm{Rb} / 10$ Hf-(3Ta); (b) Rb/30-Hf-(3Ta) (after [107]). VAG—volcanic arc granite; WPG-within-plate granite; ORG-oceanic ridge granite; COLG—collisional granite; S-COLG-syn-collisional granite; L-COLG-late-collisional granite; $\mathrm{P}-\mathrm{COLG}$ - post-collisional granite. The circles in the diagrams denote published data for the Zhuxi granites [38,42,43]. 


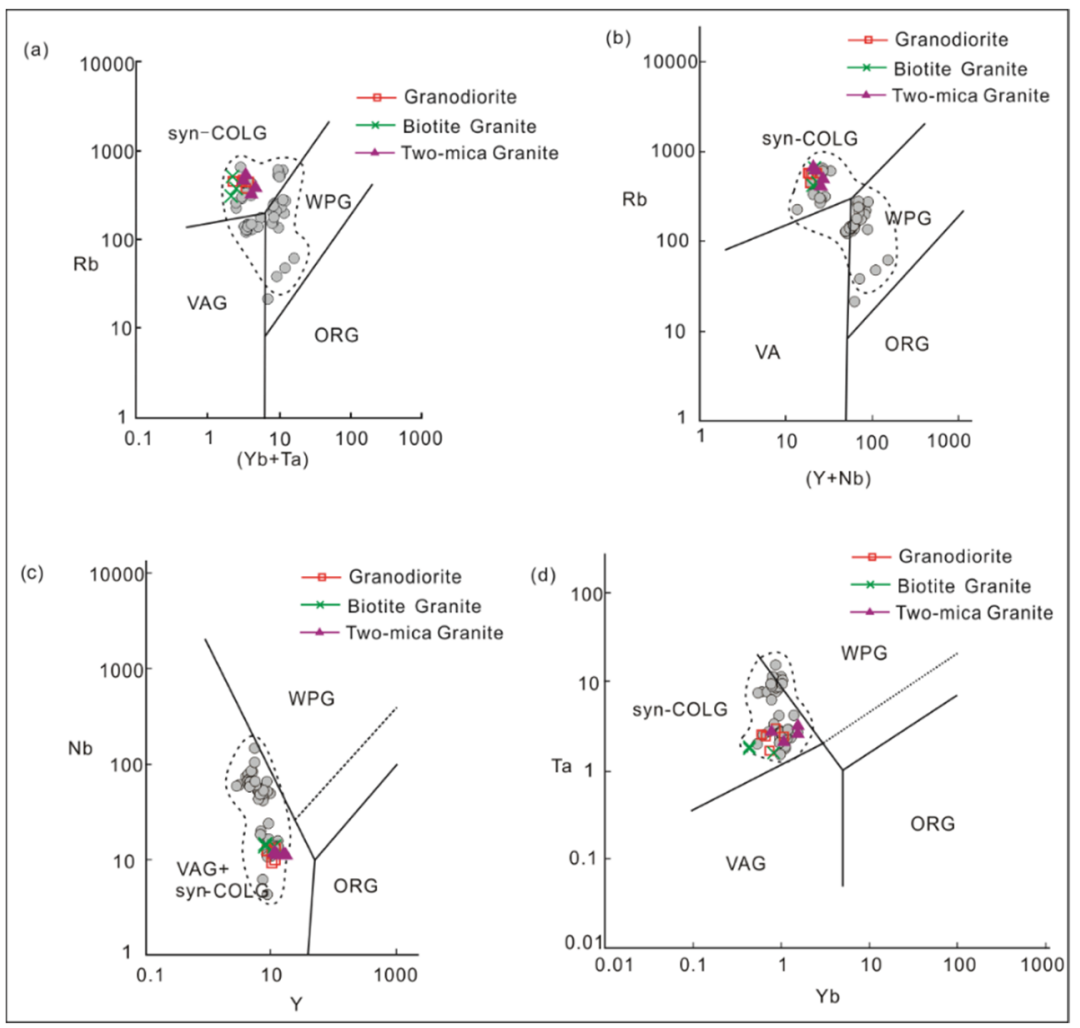

Figure 11. Geochemical classification plots for Zhuxi granites from the Jingdezhen area. (a) $\mathrm{Rb}-(\mathrm{Yb}$ + Ta); (b) Rb-(Y+ Nb); (c) Nb-Y; (d) Ta-Yb (all after [108]). Abbreviations are as for Figure 10. The circles in the diagrams denote published data for the Zhuxi granites [38,42,43].

Previous studies of the Yanshanian tectonic evolution of the SCB have proposed that the Yanshanian tectonic event in South China occurred in an intraplate setting [11,98,99,103,109]. Geochemical and isotopic characteristics indicate that the magma of this granite was formed mainly through melting of upper-crustal rocks, accompanied by large-scale thrusting and strike-slip faulting [110-112]. Previous studies have shown that the coincidence of large thrust belts, contemporaneous muscovite (two-mica) granite belts (located in the upthrown belt), and foreland fold belts (developed in the subduction zone), is one of the most important indicators of an intracontinental subduction zone [110].

The SCB underwent strong intracontinental deformation during the late Mesozoic, characterized by large-scale fold and thrust deformation [6,100,101,113-117]. The characteristics of tectonic deformation and geophysical data of the Xuefengshan fold-thrust belt and the Youjiang foreland thrust belt indicate that eastward intracontinental subduction developed in the interior of the SCB $([102,118]$. The widely developed muscovite (twomica) granite belt in the SCB, and the contemporaneous intracontinental subduction thrust tectonic belt, are therefore the products of intracontinental subduction [102,110,119].

The MPG is majority associated with the climax of intracontinental subduction and occurs where the thick continental crust is crosscut by major shear and thrust zones [70]. The formation and development of the NNE- to NE-trending fold-and-thrust system in South China records the effects of northwestward subduction of the Paleo-Pacific Plate as a remote response to subduction of the Paleo-Pacific Plate under the continental lithosphere of the SCB $[55,98,100,101,113,114]$. Additionally, the peraluminous granites (MPG) are emplaced in the intracontinental orogenic belt (e.g., the two-mica granites in the Zhuxi area, this study) by intracontinental subduction.

Previous petrological and geochemical studies of Early Jurassic to Early Cretaceous gneiss, mylonite, and intrusive rocks in the Changle-Nanao area of Fujian Province indicate that the trondhjemite-tonalite-granodiorite (TTG) rock association of the southeastern 
coastal areas was formed in an active continental-margin arc tectonic environment, related to subduction of the Paleo-Pacific Plate [120,121]. Zircon U-Pb ages and Hf isotopic data of the Qinghu monzonite and the Lisong and Fogang granites of the Nanling Range in SE China indicate that these magmas were formed in an arc setting during the Middle-Late Jurassic (179-160 Ma) [67]. Their positive $\varepsilon H f(t)$ values (6.3-13.8) indicate that the magmas were derived from partial melting of subduction-related mantle sources (Figure 12) [67]. These considerations indicate that the subduction of the Paleo-Pacific Plate to the NW or NWW played an important role in the Yanshanian tectonic-magmatic evolution of the SCB.
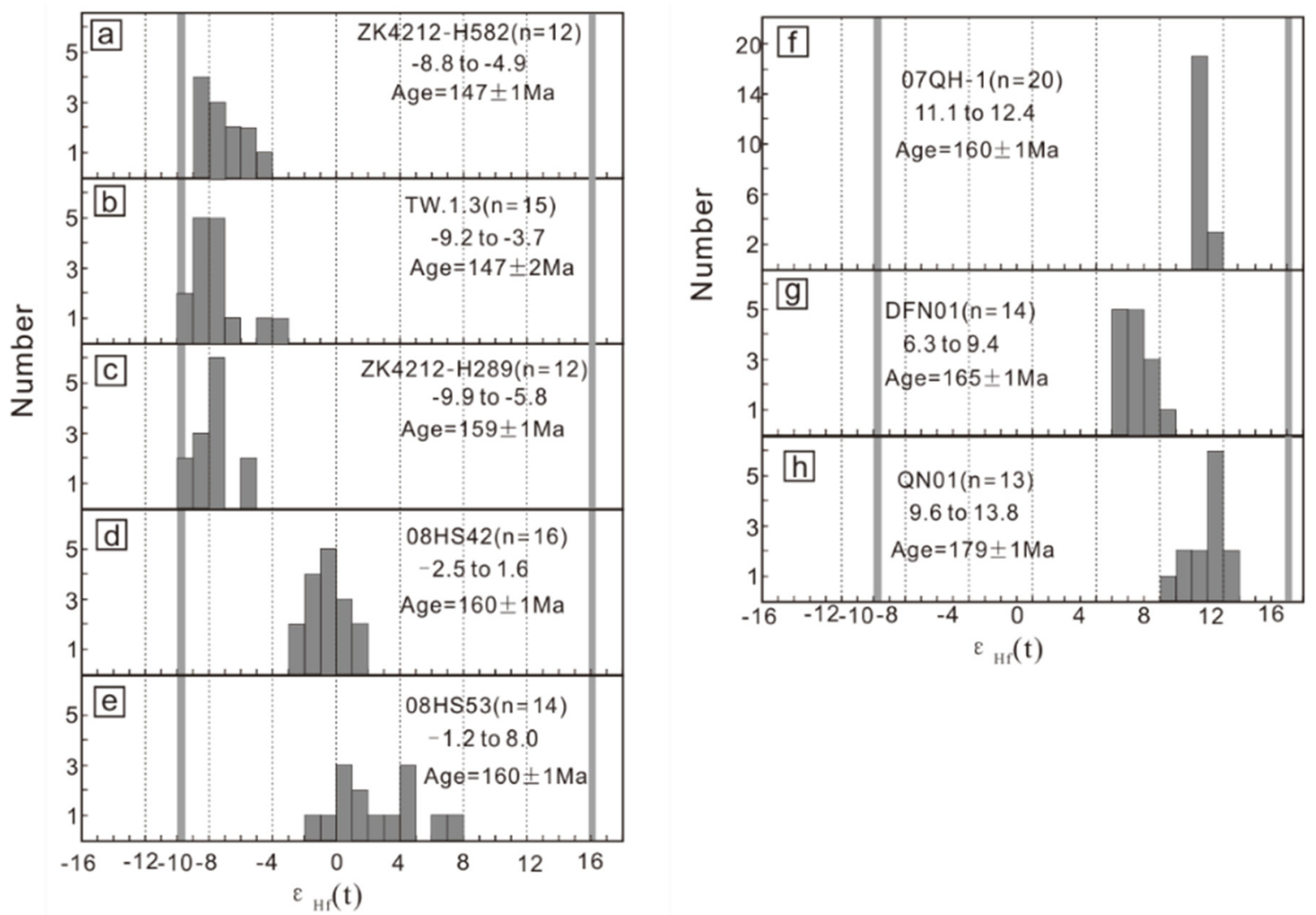

Figure 12. Frequency distributions of $\varepsilon \mathrm{Hf}(t)$ values of zircons from (a) Zhuxi two-mica granite, (b) Zhuxi biotite granite, (c) Zhuxi granodiorite, (d) Lisong monzogranite, (e) Lisong mafic microgranular enclaves, (f) Qinghu monzonite, (g) Dafengnao syenite, and (h) Huangbu syenite. The data for Lisong monzogranite, mafic microgranular enclaves, and Qinghu monzonite are from [67]; data for Dafengnao syenite and Huangbu syenite are from [122].

The TTG magmatism along the southeast coast of the SCB and the development of the muscovite (two-mica) granite belt in the inland SCB were the results of the combined effects of intracontinental and oceanic subduction (Figure 13) $[109,123,124]$. The intracontinental subduction of the Yangtze and Cathaysia blocks resulted in the superposition of two continental crusts and the thickening of the continental crust (Figure 13) [109,123]. The early Yanshanian granites in coastal areas of South China may represent the growth and differentiation of continental crust, indicating a thermally dynamic system that played a primary role in the upwelling of asthenospheric mantle and magma generation. Such extensive mantle-derived magmatism could have provided the necessary heat and materials for the generation of the widespread Yanshanian granites in South China [67,122]. 


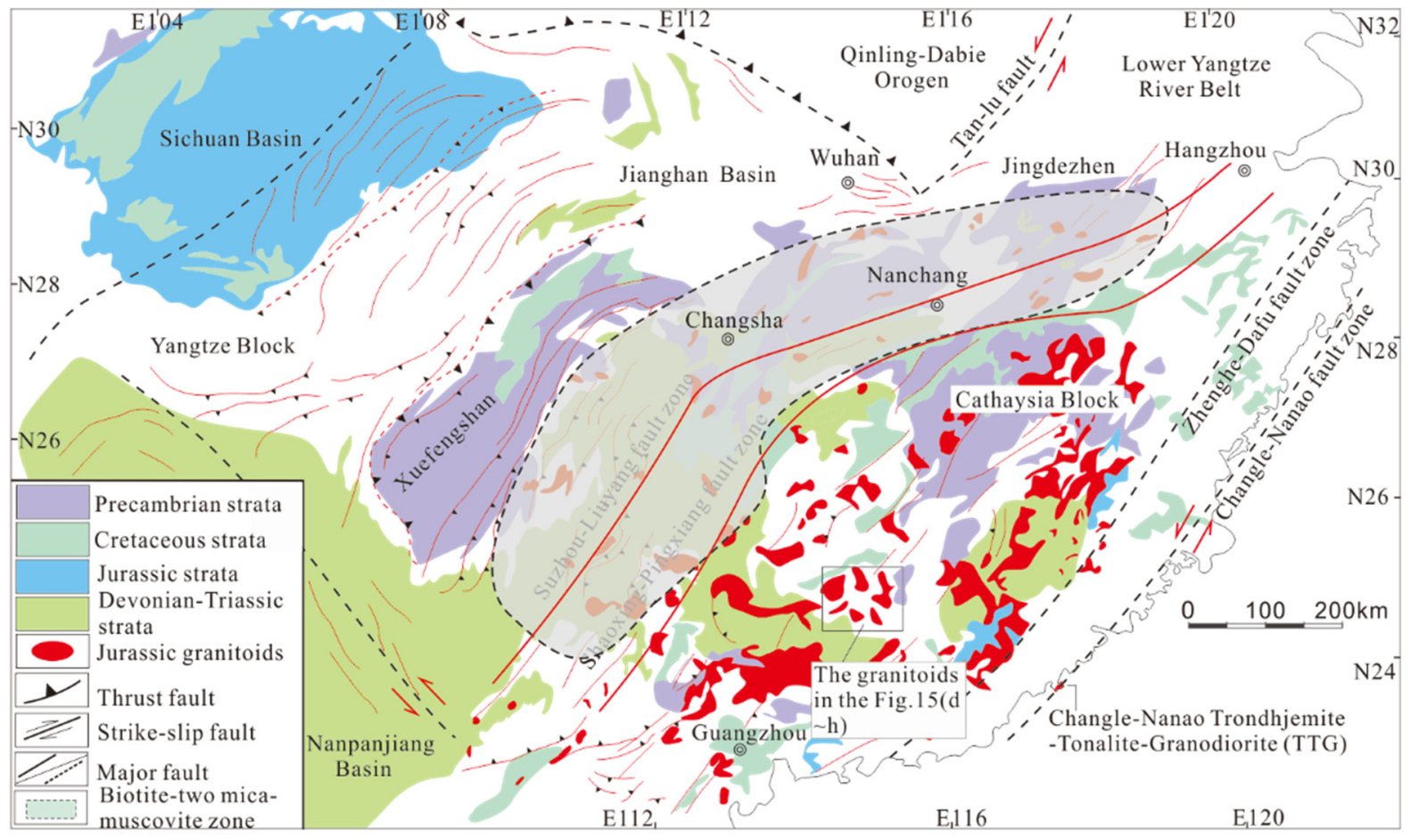

Figure 13. Simplified geological map of South China delineating the distributions of the Jurassic magmatic rocks, biotite-two-mica-muscovite zone and Changle-Nanao Trondhjemite-TonaliteGranodiorite (TTG) (modified from [109,111,122-125].

The Middle-Late Triassic (ca. 240-210 Ma) intercontinental collision between the South and North China blocks occurred along the Qinling-Dabie Orogenic Belt and was characterized by large-scale thrusting, strike-slip faulting, intense crustal shortening, followed by large-scale lithospheric extension, and A-type granite formation (Figure 14a) $[97,126,127]$. Subduction of the Indian Plate and westward subduction of the Pacific Plate resulted in the SCB entering an intracontinental deformation stage (ca. 170-145 Ma) under a background of multi-plate convergence (Figure 14b) [100-102,108,113,114].

Petrological evidence indicates that two-mica granite magma forms through partial melting of sedimentary rocks via processes associated with intracontinental subduction or intercontinental collision $[80,110,128]$. Previous studies have shown that the SCB entered an intracontinental deformation stage during the Yanshanian, without intercontinental collision (Figure 14b). Therefore, the two-mica granites in the Zhuxi granites may indicate that the magma formed via processes associated with intracontinental subduction. The combined effects of subduction of the Paleo-Pacific Plate under the SCB and intracontinental subduction of the Yangtze and Cathaysia blocks would have contributed to the formation of the Northeastern Jiangxi granites, and thus to the magmatic evolution of this region in South China. The Zhuxi granites highlights the primary role of oceanic-continental convergence and intracontinental subduction in early Yanshanian granitoid magmatism in South China (Figure 14b). The magmas were formed under a convergence tectonic regime in response to distant stresses at plate margins during subduction of the Paleo-Pacific Plate. 
(a) Indosinian period

(ca. 240-210 Ma)

Qinling-Dabie suture
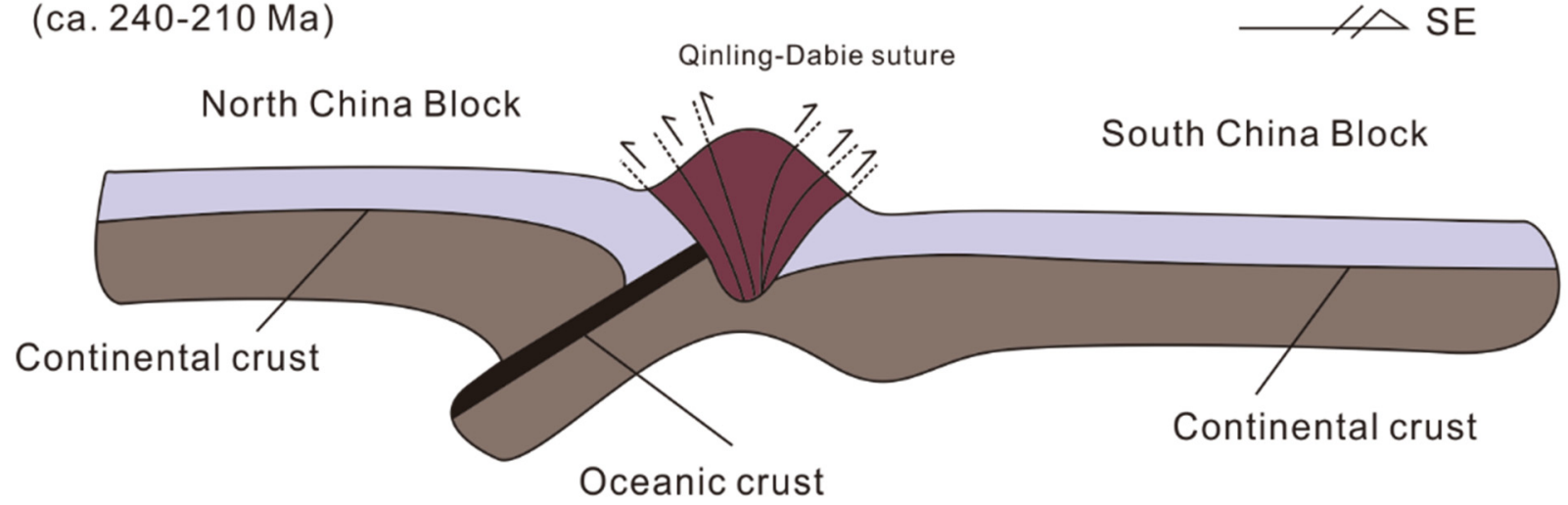

(b) Yanshanian period
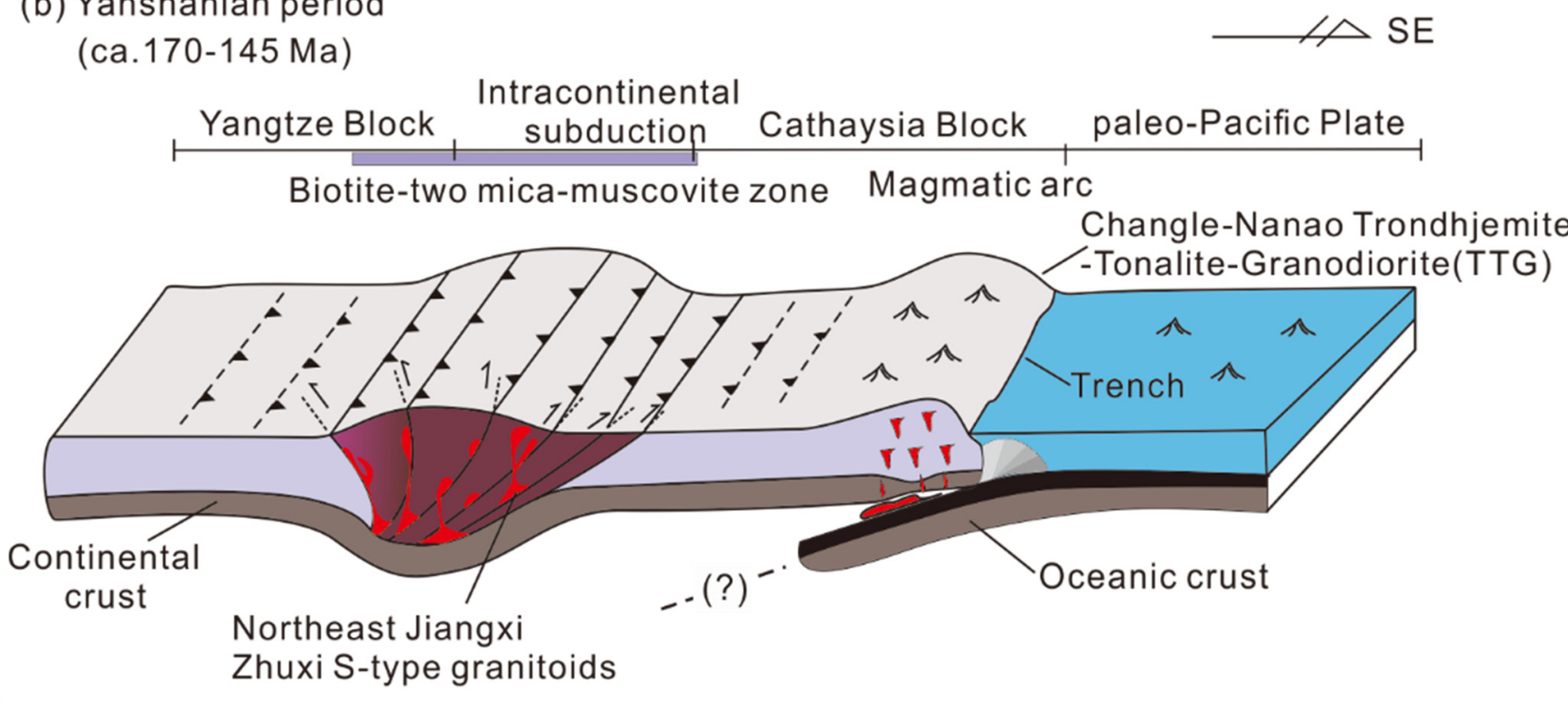

Figure 14. Tentative dynamic model of the Mesozoic tectonic evolution of South China. (a) Earlier stage (ca. 240-210 Ma) continental collision between the North and South China blocks along the Qinling-Dabie suture [97]. (b) Later stage (ca. 170-145 Ma) intracontinental subduction in response to distant stresses triggered by subduction of the Paleo-Pacific Plate (modified from [70,102].

\section{Conclusions}

(1) The LA-ICP-MS zircon U-Pb isotopic analyses of the Zhuxi granodiorite, biotite granite, and two-mica granite indicated that the Zhuxi granites were emplaced at 159-147 Ma.

(2) The presence of muscovite, combined with the strongly peraluminous granitoid nature and high potassium contents, indicated that they are S-type granites. The geochemical characteristics and Hf isotopic compositions of the granites indicated that the Zhuxi magmas were derived from partial melting of Shuangqiaoshan Group metapelites rocks of the SCB.

(3) Yanshanian tectonic and magmatic events are considered to have been a response to far-field effects of oceanic-continental convergence of the Paleo-Pacific Plate, with Yanshanian granites in the Jingdezhen area being generated in an intracontinental subduction setting. 


\begin{abstract}
Supplementary Materials: The following supporting information can be downloaded at: https:/ / www.mdpi.com/article/10.3390/min12030283/s1, Table S1: Simplified sample descriptions, mineral assemblages, sampling location, and age of the representative Zhuxi granitoid rocks, Northeast Jiangxi Province. Table S2: LA-ICP-MS U-Pb zircon ages of Zhuxi granites samples Zk4212-289, Tw13, and Zk4212-582. Table S3: Whole-rock major-oxide (wt.\%) compositions of the Zhuxi granites. Table S4: Whole-rock trace-element (ppm) compositions of the Zhuxi granites (H285-H573) and Shuangqiaoshan Group (Bzx13-(01-08)). Table S5: Zircon Hf isotopic compositions of the Zhuxi granites. Table S6: Summary of U-Pb age data for Northeastern Jiangxi and adjacent regions.
\end{abstract}

Author Contributions: Conceptualization, H.H. and D.Z.; methodology, D.Z.; software, B.H.; validation, H.H. and Z.C.; formal analysis, H.H.; investigation, H.H., X.H. and N.L.; resources, D.Z. and Y.D.; data curation, Z.C. and D.Z.; writing-original draft preparation, H.H.; writing-review and editing, Z.C. and D.Z.; visualization, D.Z.; supervision, D.Z. and Z.C.; project administration, D.Z.; funding acquisition, D.Z. and Z.C. All authors have read and agreed to the published version of the manuscript.

Funding: This study was supported by the National Natural Science Foundation of China (Grant Nos. 41772069, 42172258, 42072227, and 41502085), the Welfare Research Program of Ministry of Land and Resources, PRC (201411035-3), the National Key Technology Research and Development Program of the Ministry of Science and Technology of China (2018YFC0604005), and the China Geological Survey Bureau (DZLXJK202002).

Data Availability Statement: Not applicable.

Acknowledgments: We are grateful for the assistance during fieldwork provided by Guohua Chen, Yongpeng Ouyang, and Jing Wei from the 912 Geological Team, Bureau of Geology and Mineral Resources of Jiangxi Province, Yingtan, China.

Conflicts of Interest: The authors declare no conflict of interest.

\title{
References
}

1. Charvet, J.; Lapierre, H.; Yu, Y.W. Geodynamic significance of the Mesozoic volcanism of Southeastern China. J. Asian Earth Sci. 1994, 9, 387-396. [CrossRef]

2. Charvet, J. Late Paleozoic-Mesozoic tectonic evolution of SW Japan: A review-Reappraisal of the accretionary orogeny and revalidation of the collisional model. J. Asian Earth Sci. 2013, 72, 88-101. [CrossRef]

3. Guo, L.Z.; Shi, Y.S.; Lu, H.F.; Ma, R.S.; Dong, H.G.; Yang, S.F. The Pre-devonian tectonic patterns and evolution of South China. J. Asian Earth Sci. 1989, 3, 87-93.

4. Li, X.H.; Li, Z.X.; Ge, W.; Zhou, H.; Li, W.; Liu, Y.; Wingate, M.T.D. Neoproterozoic granitoids in South China: Crustal melting above a mantle plume at ca. 825 ma? Precambrian Res. 2003, 122, 45-83. [CrossRef]

5. Li, S.Z.; Zhang, G.W.; Zhou, L.H.; Zhao, G.C.; Liu, X.; Sun, Y.H.; Dai, L.M. The opposite Meso-Cenozoic intracontinental deformations under the super-convergence: Rifting and extension in the North China Craton and shortening and thrusting in the South China Craton. Earth Sci. Front. 2011, 18, 79-107. (In Chinese with English abstract)

6. Zhang, G.W.; Guo, A.L.; Wang, Y.J.; Li, S.Z.; Dong, Y.P.; Liu, S.F.; Yao, A.P. Tectonics of South China continent and its implications. Sci. China Earth Sci. 2013, 56, 1804-1828. (In Chinese with English abstract) [CrossRef]

7. Zhao, G.C.; Guo, J.H. Precambrian geology of China: Preface. Precambrian Res. 2012, 222-223, 1-12. [CrossRef]

8. Zheng, Y.F.; Wu, R.X.; Wu, Y.B.; Zhang, S.B.; Yuan, H.L.; Wu, F.Y. Rift melting of juvenile arc-derived crust: Geochemical evidence from Neoproterozoic volcanic and granitic rocks in the Jiangnan Orogen, South China. Precambrian Res. 2008, 163, $351-383$. [CrossRef]

9. Deng, Z.B.; Liu, S.W.; Zhang, L.F.; Wang, Z.Q.; Wang, W.; Yang, T.; Guo, B.R. Geochemistry, zircon U-Pb and Lu-Hf isotopes of an Early Cretaceous intrusive suite in Northeastern Jiangxi Province, South China Block: Implications for petrogenesis, crust/mantle interactions and geodynamic processes. Lithos 2014, 200, 334-354. [CrossRef]

10. Li, X.H. Cretaceous magmatism and lithospheric extension in Southeast China. J. Asian Earth Sci. 2000, 18, 293-305. [CrossRef]

11. Shu, L.S.; Faure, M.; Wang, B.; Zhou, X.M.; Song, B. Late Paleozoic-Early Mesozoic geological features of South China: Response to the Indosinian collision event in Southeast Asia. Comptes Rendus Géoscience 2008, 340, 151-165. [CrossRef]

12. Shu, L.S.; Zhou, X.M.; Deng, P.; Wang, B.; Jiang, S.Y.; Yu, J.H.; Zhao, X.X. Mesozoic tectonic evolution of the Southeast China Block: New insights from basin analysis. J. Asian Earth Sci. 2009, 34, 376-391. [CrossRef]

13. Wang, Y.J.; Fan, W.M.; Sun, M.; Liang, X.Q.; Zhang, Y.H.; Peng, T.P. Geochronological, geochemical and geothermal constraints on petrogenesis of the Indosinian peraluminous granites in the South China Block: A case study in the Hunan province. Lithos 2007, 96, 475-502. [CrossRef] 
14. Wang, X.L.; Zhao, G.C.; Zhou, J.C.; Liu, Y.S.; Hu, J. Geochronology and Hf isotopes of zircon from volcanic rocks of the Shuangqiaoshan Group, South China: Implications for the Neoproterozoic tectonic evolution of the eastern Jiangnan orogen. Gondwana Res. 2008, 14, 355-367. [CrossRef]

15. Wang, X.L.; Zhou, J.C.; Qiu, J.S.; Gao, J.F. Geochemistry of the Meso- to Neoproterozoic basic-acid rocks from Hunan Province, South China: Implications for the evolution of the western Jiangnan orogen. Precambrian Res. 2004, 135, 79-103. [CrossRef]

16. Wang, X.L.; Zhou, J.C.; Qiu, J.S.; Zhang, W.L.; Liu, X.M.; Zhang, G.L. LA-ICP-MS U-Pb zircon geochronology of the Neoproterozoic igneous rocks from Northern Guangxi, South China: Implications for tectonic evolution. Precambrian Res. 2006, 145, 111-130. [CrossRef]

17. Wang, Y.J.; Fan, W.M.; Cawood, P.A.; Li, S. Sr-Nd-Pb isotopic constraints on multiple mantle domains for Mesozoic mafic rocks beneath the South China Block hinterland. Lithos 2008, 106, 297-308. [CrossRef]

18. Wang, Y.J.; Zhang, A.E.; Fan, W.M.; Zhao, G.C.; Zhang, G.W.; Zhang, Y.Z.; Li, S.Z. Kwangsian crustal anatexis within the eastern South China Block: Geochemical, Zircon U-Pb geochronological and Hf isotopic fingerprints from the gneissoid granites of Wugong and Wuyi-Yunkai Domains. Lithos 2011, 127, 239-260. [CrossRef]

19. Wang, D.Z.; Shu, L.S. Late Mesozoic basin and range tectonics and related magmatism in Southeast China. Geosci. Front. 2012, 3, 109-124. [CrossRef]

20. Xu, X.B.; Xue, D.J.; Li, Y.; Hu, P.; Chen, N.S. Neoproterozoic sequences along the Dexing-Huangshan fault zone in the eastern Jjiangnan orogen, South China: Geochronological and geochemical constrains. Gondwana Res. 2014, 25, 368-382. [CrossRef]

21. Yu, X.Q.; Wu, G.G.; Zhao, X.X.; Gao, J.F.; Di, Y.J.; Zheng, Y.; Qiu, J.T. The Early Jurassic tectono-magmatic events in southern Jiangxi and northern Guangdong provinces, SE China: Constraints from the SHRIMP zircon U-Pb dating. J. Asian Earth Sci. 2010, 39, 408-422. [CrossRef]

22. Wong, J.; Sun, M.; Xing, G.F.; Li, X.H.; Zhao, G.C.; Wong, K.; Yuan, C.; Wu, F.Y. Geochemical and zircon U-Pb and Hf isotopic study of the Baijuhuajian metaluminous A-type granite: Extension at 125-100 Ma and its tectonic significance for South China. Lithos 2009, 112, 289-305. [CrossRef]

23. Meng, L.F.; Li, Z.X.; Chen, H.L.; Li, X.H.; Zhu, C. Detrital zircon U-Pb geochronology, Hf isotopes and geochemistry constraints on crustal growth and mesozoic tectonics of southeastern China. J. Asian Earth Sci. 2015, 105, 286-299. [CrossRef]

24. Wang, X.L.; Shu, X.J.; Xu, X.; Tang, M.; Gaschnig, R. Petrogenesis of the Early Cretaceous adakite-like porphyries and associated basaltic andesites in the eastern Jiangnan orogen, southern China. J. Asian Earth Sci. 2012, 61, 243-256. [CrossRef]

25. Wong, J.; Sun, M.; Xing, G.F.; Li, X.H.; Zhao, G.C.; Wong, K.; Wu, F.Y. Zircon U-Pb and Hf isotopic study of Mesozoic felsic rocks from eastern Zhejiang, South China: Geochemical contrast between the Yangtze and Cathaysia blocks. Gondwana Res. 2011, 19, 244-259. [CrossRef]

26. Zhao, L.; Guo, F.; Fan, W.M.; Zhang, Q.W.; Wu, Y.M.; Li, J.Y.; Yan, W. Early Cretaceous potassic volcanic rocks in the Jiangnan Orogenic Belt, East China: Crustal melting in response to subduction of the Pacific-Izanagi ridge? Chem. Geol. 2016, 437, 30-43. [CrossRef]

27. Zhong, Y.F.; Ma, C.Q.; Liu, L.; Zhao, J.H.; Zheng, J.P.; Nong, J.; Zhang, Z.J. Ordovician appinites in the Wugongshan Domain of the Cathaysia Block, South China: Geochronological and geochemical evidence for intrusion into a local extensional zone within an intracontinental regime. Lithos 2014, 198, 202-216. [CrossRef]

28. Chen, G.H.; Wan, H.Z.; Shu, L.S.; Zhang, C.; Kang, C. An analysis on ore-controlling conditions and geological features of the $\mathrm{Cu}-\mathrm{W}$ polymetallic ore deposit in the Zhuxi area of Jingdezhen, Jiangxi Province. Acta Petrol. Sin. 2012, 28, 3901-3914. (In Chinese with English abstract)

29. Chen, G.H.; Shu, L.S.; Shu, L.M.; Zhang, C.; Ouyang, Y.P. Geological characteristics and mineralization setting of the Zhuxi tungsten (copper) polymetallic deposit in the Eastern Jiangnan Orogen. Sci. China Earth Sci. 2015, 59, 803-823. [CrossRef]

30. Huo, H.L.; Zhang, D.; Wu, G.G.; Chen, Z.L.; Di, Y.J.; Chen, G.H.; Li, N. Zircon U-Pb Ages and Hf Isotopes of the Volcanic Clastic Tuff from the Shuangqiaoshan Group in Jingdezhen, Northeastern Jiangxi Province. Bull. Mineral. Petrol. Geochem. 2018, 37, 103-110. (In Chinese with English abstract)

31. Shu, L.S. An analysis of principal features of tectonic evolution in South China Block. Geol. Bull. China 2012, 31, 1035-1053. (In Chinese with English abstract)

32. Wang, X.L.; Zhou, J.C.; Griffin, W.L.; Wang, R.C.; Qiu, J.S.; Reilly, S.Y.; Zhang, G.L. Detrital zircon geochronology of Precambrian basement sequences in the Jiangnan orogen: Dating the assembly of the Yangtze and Cathaysia Blocks. Precambrian Res. 2007, 159, 117-131. [CrossRef]

33. Wang, Y.J.; Fan, W.M.; Zhang, G.W.; Zhang, Y.H. Phanerozoic tectonics of the South China Block: Key observations and controversies. Gondwana Res. 2013, 23, 1273-1305. [CrossRef]

34. Wang, W.; Zhou, M.F.; Yan, D.P.; Li, L.; Malpas, J. Detrital zircon record of Neoproterozoic active-margin sedimentation in the eastern Jiangnan Orogen, South China. Precambrian Res. 2013, 235, 1-19. [CrossRef]

35. BGMRJX (Bureau of Geology and Mineral Resources of Jiangxi Province). Regional Geology of Jiangxi Autonomous Region; Geological Publishing House: Beijing, China, 1996. (In Chinese with English abstract)

36. Liu, J.W.; Chen, B.; Chen, J.S.; Li, Z.; Sun, K.K. Highly differentiated granite from the Zhuxi tungsten (copper) deposit in northeastern Jiangxi Province: Petrogenesis and their relationship with W-mineralization. Acta Petrol. Sin. 2017, 33, 3161-3182. (In Chinese with English abstract) 
37. Pan, X.F.; Hou, Z.Q.; Li, Y.; Chen, G.H.; Zhao, M.; Zhang, T.F.; Zhang, C.; Kang, C. Dating the giant Zhuxi W-Cu deposit (Taqian-Fuchun Ore Belt) in South China using molybdenite Re-Os and muscovite Ar-Ar system. Ore Geol. Rev. 2017, 86, 719-733. [CrossRef]

38. Pan, X.F.; Hou, Z.Q.; Zhao, M.; Chen, G.H.; Rao, J.F.; Li, Y.; Ouyang, Y.P. Geochronology and geochemistry of the granites from the Zhuxi W-Cu ore deposit in South China: Implication for petrogenesis, geodynamical setting and mineralization. Lithos 2018, 304-307, 155-179. [CrossRef]

39. Wang, C.B.; Rao, J.F.; Chen, G.H.; Ouyang, Y.P.; Qi, S.J.; Li, Q. Prospectivity mapping for "Zhuxi-type" Copper-Tungsten Polymetallic Deposits in the Jingdezhen Region of Jiangxi Province, South China. Ore Geol. Rev. 2017, 89, 1-14. [CrossRef]

40. Xu, X.B.; Tang, S.; Lin, S.F. Detrical provenance of Early Mesozoic basins in the Jiangnan domain, South China: Paleogeographic and geodynamic implications. Tectonophysics 2016, 675, 141-158. [CrossRef]

41. Li, Y.; Pan, X.F.; Zhao, M.; Chen, G.H.; Zhang, T.F.; Liu, X.; Zhang, C. LA-ICP-MS Zircon U-Pb Age, Geochemical Features and Relations to the W-Cu Mineralization of Granitic Porphyry in Zhuxi Skarn Deposit, Jingdezhen, Jiangxi. Geol. Rev. 2014, 60, 693-708. (In Chinese with English abstract)

42. Li, N. Study on Granite and Mineralization of Zhuxi W-Cu Deposit, Northeast of Jiangxi Province. Master's Thesis, China University of Geosciences, Beijing, China, 2017; pp. 21-80. (In Chinese with English abstract)

43. Song, S.W.; Mao, J.W.; Zhu, Y.F.; Yao, Z.Y.; Chen, G.H.; Rao, J.F.; Ouyang, Y.P. Partial-melting of fertile metasedimentary rocks controlling the ore formation in the Jiangnan porphyry-skarn tungsten belt, south China: A case study at the giant Zhuxi W-Cu skarn deposit. Lithos 2018, 304-307, 180-199. [CrossRef]

44. Song, S.W.; Mao, J.W.; Xie, G.Q.; Yao, Z.Y.; Chen, G.H.; Rao, J.F.; Ouyang, Y.P. The formation of the world-class Zhuxi scheelite skarn deposit: Implications from the petrogenesis of scheelite-bearing anorthosite. Lithos 2018, 312-313, 153-170. [CrossRef]

45. Zhou, X.H.; Zhang, Y.J.; Liao, S.B.; Yu, M.G.; Chen, Z.H.; Zhao, X.L.; Jiang, Y. LA-ICP-MS Zircon U-Pb Geochronology of Volcanic Rocks in the Shuangqiaoshan Group at Anhui-Jiangxi Boundary Region and Its Geological Implication. Geol. J. China Univ. 2012, 18, 609-622. (In Chinese with English abstract)

46. Gao, L.Z.; Yang, M.G.; Ding, X.Z.; Liu, Y.X.; Liu, X.; Ling, L.H.; Zhang, C.H. SHRIMP U-Pb zircon dating of tuff in the Shuangqiaoshan and Heshangzhen groups in South China-constraints on the evolution of the Jiangnan Neoproterozoic orogenic belt. Geol. Bull. China 2008, 27, 1744-1751. (In Chinese with English abstract)

47. Huang, H.Q.; Li, X.H.; Li, Z.X.; Li, W.X. Formation of the Jurassic South China Large Granitic Province: Insights from the genesis of the Jiufeng pluton. Chem. Geol. 2015, 401, 43-58. [CrossRef]

48. Huang, L.C.; Jiang, S.Y. Geochronology, geochemistry and petrogenesis of the tungsten-bearing porphyritic granite in the Dahutang tungsten deposit, Jiangxi Province. Acta Petrol. Sin. 2013, 29, 4323-4335. (In Chinese with English abstract)

49. Dong, S.W.; Xue, H.M.; Xiang, X.K.; Ma, L.C. The discovery of Neoproterozoic pillow lava in spilite-ceratophyre of Lushan area, northern Jiangxi Province, and its geological significance. Geol. China 2010, 37, 1021-1033. (In Chinese with English abstract)

50. Liu, S.W.; Yang, P.T.; Wang, Z.Q.; Luo, P.; Wang, Y.Q.; Luo, G.H.; Guo, B.R. LA-ICP-MS zircon U-Pb ages and geochemistry of Neoproterozoic low-grade metavolcanic rocks in Wuyuan-Dexing area of northeastern Jianxi Province. Acta Petrol. Sin. 2013, 29, 581-593. (In Chinese with English abstract)

51. Duan, Z.; Xing, G.F.; Liao, S.B.; Chu, P.L.; Huang, W.C.; Zhu, Y.H. Compositional difference from the sources of Jiuling Neoproterozoic granite complex in Eastern Segment of the Jiangnan Orogen: Constraints from geochemistry and Hf isotope of zircons. Acta Petrol. Sin. 2017, 33, 3610-3634. (In Chinese with English abstract)

52. Wan, H.Z.; Liu, Z.Q.; Liu, S.B.; Chen, Y.C.; Wang, C.H.; Chen, G.H.; Liu, X.L. LA-ICP-MS zircon U-Pb dating of granodioritic porphyry located zhuxi copper-tungsten mine in Northeast Jiangxi and its Geological significance. Rock Miner. Anal. 2015, 34, 494-502. (In Chinese with English abstract)

53. Xue, H.M.; Ma, F.; Song, Y.Q.; Xie, Y.P. Geochronology and geochemisty of the Neoproterozoic granitoid association from eastern segment of the Jiangnan orogen, China: Constraints on the timing and process of amalgamation between the Yangtze and Cathaysia blocks. Acta Petrol. Sin. 2010, 26, 3215-3244. (In Chinese with English abstract)

54. Zhang, F.F.; Wang, Y.J.; Fan, W.M.; Zhang, A.M.; Zhang, Y.Z. Zircon U-Pb Geochronology and Hf isotopes of the Neoproterozoic Granites in the Central of Jiangnan Uplift. Geotecton. Et Metallog. 2011, 35, 73-84. (In Chinese with English abstract)

55. Xiao, W.J.; He, H.Q. Early Mesozoic thrust tectonics of the northwest Zhejiang region (Southeast China). Geol. Soc. Am. Bull. 2005, 117, 945-961. [CrossRef]

56. Dong, S.W.; Zhang, Y.Q.; Li, H.L.; Shi, W.; Xue, H.M.; Li, J.H.; Huang, S.Q.; Wang, Y.C. The Yanshan orogeny and late Mesozoic multi-plate convergence in East Asia-Commemorating 90th years of the "Yanshan Orogeny". Sci. China Earth Sci. 2018, 61, 1888-1909. [CrossRef]

57. Ludwig, K.R. User's Manual for Isoplot 3.00. A Geochronological Toolkit for Microsoft Excel: Berkeley Geochronology Center; No. 4a; Special Publication: Berkeley, CA, USA, 2003.

58. Stacey, J.S.; Kramers, J.D. Approximation of terrestrial lead isotope evolution by a two-stage model. Earth Planet. Sci. Lett. 1975, 26, 207-221. [CrossRef]

59. Li, X.H. Geochemistry of the Longsheng Ophiolite from the southern margin of Yangtze Craton, SE China. Geochem. J. 1997, 31, 323-337. [CrossRef]

60. Geng, J.Z.; Li, H.K.; Zhang, J.; Zhou, H.Y.; Li, H.M. Zircon Hf isotope analysis by means of LA-MC-ICP-MS. Geol. Bull. China 2011, 30, 1508-1513. (In Chinese with English abstract) 
61. Irvine, T.N.; Baragar, W.R.A. A guide to the chemical classification of the common volcanic rocks. Can. J. Earth Sci. 1971, 8, 523-548. [CrossRef]

62. Le Bas, M.J.; Le Maitre, R.W.; Streckeisen, A.; Zanettin, B. A Chemical Classification of Volcanic Rocks Based on the Total Alkali-Silica Diagram. J. Petrol. 1986, 27, 745-750. [CrossRef]

63. Peccerillo, A.; Taylor, S.R. Geochemistry of Eocene calk-alkaline volcanic rocks from the Kastamonu area, northern Turkey. Contrib. Mineral. Petrol. 1976, 58, 63-81. [CrossRef]

64. Maniar, P.D.; Piccoli, P.M. Tectonic discrimination of granitoids. Geol. Soc. Am. Bull. 1989, 101, 635-643. [CrossRef]

65. Boynton, W.V. Cosmochemistry of the Rare Earth Elements: Meteorite Studies. In Rare Earth Element Geochemistry; Henderson, P., Ed.; Elsevier: Amsterdam, The Netherlands, 1984; pp. 63-114.

66. Sun, S.S.; McDonough, W.F. Chemical and isotopic systematics of oceanic basalts: Implications for mantle composition and processes. Geol. Soc. Lond. Spec. Publ. 1989, 42, 313-345. [CrossRef]

67. Li, X.H.; Li, W.X.; Wang, X.C.; Li, Q.L.; Yu, L.; Tang, G.Q. Role of mantle-derived magma in genesis of early Yanshanian granites in the Nanling Range, South China: In situ zircon Hf-O isotopic constraints. Sci. China Ser. D Earth Sci. 2009, 52, 1262-1278. [CrossRef]

68. Zhou, X.M.; Li, W.X. Origin of Late Mesozoic igneous rocks in Southeastern China: Implications for lithosphere subduction and underplating of mafic magmas. Tectonophysics 2000, 326, 269-287. [CrossRef]

69. Liu, J.G.; Yang, X.P.; Zhou, Y.X.; Zeng, X.H.; Rao, J.F.; Liu, W.; Chen, G.H. Genesis of granites and relationship of mineralization in Zhuxi tungsten- copper deposit, Fuliang County, Jiangxi Province. Resour. Surv. Environ. 2015, 36, 276-284. (In Chinese with English abstract)

70. Barbarin, B. A review of the relationships between granitoid types, their origins and their geodynamic environments. Lithos 1999, 46, 605-626. [CrossRef]

71. Chappell, B.J.; White, A.J.R. Two Contrasting Granite Type. Pac. Geol. 1974, 8, 173-174.

72. Clemens, J.D. S-type granitic magmas-petrogenetic issues, models and evidence. Earth-Sci. Rev. 2003, 61, 1-18. [CrossRef]

73. Scaillet, B.; Holtz, F.; Pichavant, M. Experimental Constraints on the Formation of Silicic Magmas. Elements 2016, 12, 109-114. [CrossRef]

74. Huang, L.C.; Jiang, S.Y. Highly fractionated S-type granites from the giant Dahutang tungsten deposit in Jiangnan Orogen, Southeast China: Geochronology, petrogenesis and their relationship with W-mineralization. Lithos 2014, 202-203, 207-226. [CrossRef]

75. Whittington, A.G.; Treloar, P.J. Crustal anatexis and its relation to the exhumation of collisional orogenic belts, with particular reference to the Himalaya. Mineral. Mag. 2002, 66, 53-91. [CrossRef]

76. Martínez, E.M.; Villaseca, C.; Orejana, D.; Pérez-Soba, C.; Belousova, E.; Andersen, T. Tracing magma sources of three different S-type peraluminous granitoid series by in situ $\mathrm{U}-\mathrm{Pb}$ geochronology and Hf isotope zircon composition: The Variscan Montes de Toledo batholith (central Spain). Lithos 2014, 200-201, 273-298. [CrossRef]

77. Teixeira, R.J.S.; Neiva, A.M.R.; Gomes, M.E.P.; Corfu, F.; Cuesta, A.; Croudace, I.W. The role of fractional crystallization in the genesis of early syn-D3, tin-mineralized Variscan two-mica granites from the Carrazeda de Ansiães area, northern Portugal Lithos 2012, 153, 177-191. [CrossRef]

78. Wang, W.; Zhou, M.F.; Zhao, J.H.; Manoj, K.P.; Zheng, J.P.; Liu, Z.R. Neoproterozoic active continental margin in the southeastern Yangtze Block of South China: Evidence from the ca. 830-810 Ma sedimentary strata. Sediment. Geol. 2016, 342, 254-267. [CrossRef]

79. Griffin, W.L.; Wang, X.; Jackson, S.E.; Pearson, N.J.; Reilly, S.Y.; Xu, X.S.; Zhou, X.M. Zircon chemistry and magma mixing, SE China: In-situ analysis of Hf isotopes, Tonglu and Pingtan igneous complexes. Lithos 2002, 61, 237-269. [CrossRef]

80. Sylvester, P.J. Post-collisional strongly peraluminous granites. Lithos 1998, 45, 29-44. [CrossRef]

81. Wei, C.J. Granulite facies metamorphism and petrogenesis of granite (II): Quantitative modeling of the HT-UHT phase equilibria for metapelites and the petrogenesis of S-type granite. Acta Petrol. Sin. 2016, 32, 1625-1643. (In Chinese with English abstract)

82. Philpotts, J.A.; Schnetzler, C.C. Phenocryst-matrix partition coefficients for K, Rb, Sr and Ba, with applications to anorthosite and basalt genesis. Geochim. Cosmochim. Acta 1970, 34, 307-322. [CrossRef]

83. Arth, J.G. Behavior of trace elements during magmatic processes-A summary of theoretical models and their applications. J. Res. United States Geol. Surv. 1976, 4, 41-47.

84. Fujimaki, H. Partition coefficients of Hf, Zr, and REE between zircon, apatite, and liquid. Contrib. Mineral. Petrol. 1986, 94, 42-45. [CrossRef]

85. Mahood, G.; Hildreth, W. Large partition coefficients for trace elements in highsilica rhyolites. Geochim. Cosmochim. Acta 1983, 47, 11-30. [CrossRef]

86. Yurimoto, H.; Duke, E.F.; Papike, J.J.; Shearer, C.K. Are discontinuous chondritenormalized REE patterns in pegmatitic granite systems the results of monazite fractionation? Geochim. Cosmochim. Acta 1990, 54, 2141-2145. [CrossRef]

87. Li, Z.L.; Zhou, J.; Mao, J.R.; Santosh, M.; Yu, M.G.; Li, Y.Q.; Hu, Y.H. Zircon U-Pb geochronology and geochemistry of two episodes of granitoids from the northwestern Zhejiang Province, SE China: Implication for magmatic evolution and tectonic transition. Lithos 2013, 179, 334-352. [CrossRef] 
88. Liu, Z.Q.; Liu, S.B.; Chen, Y.C.; Wang, C.H.; Wan, H.Z.; Chen, G.H.; Liang, L.J. LA-ICP-MS Zircon U-Pb Isotopic Dating of Lamprophyre Located Zhuxi Copper-Tungsten Mine of Jiangxi Province and Its Geological Significance. Rock Miner. Anal. 2014, 33, 758-766. (In Chinese with English abstract)

89. Wang, X.G.; Liu, Z.Q.; Liu, S.B.; Wang, C.H.; Liu, J.G.; Wan, H.Z.; Liu, X.L. LA-ICP-MS Zircon U-Pb Dating and Petrologic Geochemistry of Fine-grained Granite from Zhuxi Cu-W Deposit, Jiangxi Province and Its Geological Significance. Rock Miner. Anal. 2015, 34, 592-599. (In Chinese with English abstract)

90. Liu, S.B.; Wang, C.H.; Liu, Z.Q.; Liu, J.G.; Wang, H.Z.; Chen, G.H.; Zhang, X.L. Northeast Jiangxi Taqian-Fuchun Metallogenic Belt Magmatite Time Limit and Sequence Division and Its Significance. Rock Miner. Anal. 2014, 33, 598-611. (In Chinese with English abstract)

91. Liang, X.Q.; Dong, C.G.; Jiang, Y.; Wu, S.C.; Zhou, Y.; Zhu, H.F.; Shan, Y.H. Zircon U-Pb, molybdenite Re-Os and muscovite Ar-Ar isotopic dating of the Xitian W-Sn polymetallic deposit, eastern Hunan Province, South China and its geological significance. Ore Geol. Rev. 2016, 78, 85-100. [CrossRef]

92. Liu, J.; Mao, J.W.; Ye, P.S.; Xie, G.Q.; Yang, G.Q.; Zhang, W. Zircon LA-ICP-MS U-Pb dating of Hukeng granite in Wugongshan area, Jiangxi Province and its geoehemical characteristics. Acta Petrol. Sin. 2008, 24, 1813-1822. (In Chinese with English abstract)

93. Mao, Z.H.; Liu, J.J.; Mao, J.W.; Deng, J.; Zhang, F.; Meng, X.X.; Luo, X.H. Geochronology and geochemistry of granitoids related to the giant Dahutang tungsten deposit, middle Yangtze River region, China: Implications for petrogenesis, geodynamic setting, and mineralization. Gondwana Res. 2015, 28, 816-836. [CrossRef]

94. Hsü, K.J.; Sun, S.; Li, J.L. Huanan Alps, not South China Platform. Sci. China Ser. B 1988, 31, 109-119.

95. Hsü, K.J.; Sun, S.; Li, J.L.; Chen, H.H.; Pen, H.P.; Şengör, A.M.C. Mesozoic overthrust tectonics in South China. Geology 1988, 16, 418-421. [CrossRef]

96. Hsü, K.J.; Li, J.; Chen, H.; Wang, Q.; Sun, S.; Şengör, A.M.C. Tectonics of South China: Key to understanding West Pacific geology. Tectonophysics 1990, 183, 9-39. [CrossRef]

97. Liu, X.C.; Jahn, B.M.; Liu, D.Y.; Dong, S.W.; Li, S.Z. SHRIMP U-Pb zircon dating of a metagabbro and eclogites from western Dabieshan (Hong'an Block), China, and its tectonic implications. Tectonophysics 2004, 394, 171-192. [CrossRef]

98. Zhang, Y.Q.; Xu, X.B.; Jia, D.; Shu, L.S. Deformation record of the change from Indosinian collision-related tectonic system to Yanshanian subduction-related tectonic system in South China during the Early Mesozoic. Earth Sci. Front. 2009, 16, 234-247. (In Chinese with English abstract)

99. Zhang, Y.Q.; Dong, S.W.; Li, J.H.; Cui, J.J.; Shi, W.; Su, J.B.; Li, Y. The new Progress in the Study of Mesozoic Tectonics of South China. Acta Geosci. Sin. 2012, 33, 257-279. (In Chinese with English abstract)

100. Li, J.H.; Zhang, Y.Q.; Dong, S.W.; Shi, W. Structural and geochronological constraints on the Mesozoic tectonic evolution of the North Dabashan zone, South Qinling, central China. J. Asian Earth Sci. 2013, 64, 99-114. [CrossRef]

101. Li, J.H.; Zhang, Y.Q.; Dong, S.W.; Su, J.B.; Li, Y.; Cui, J.J.; Shi, W. The Hengshan low-angle normal fault zone: Structural and geochronological constraints on the Late Mesozoic crustal extension in South China. Tectonophysics 2013, 606, 97-115. [CrossRef]

102. Li, J.H.; Zhao, G.C.; Johnston, S.T.; Dong, S.W.; Zhang, Y.Q.; Xin, Y.J.; Yu, Y.Q. Permo-Triassic structural evolution of the Shiwandashan and Youjiang structural belts, South China. J. Struct. Geol. 2017, 100, 24-44. [CrossRef]

103. Faure, M.; Shu, L.S.; Wang, B.; Charvet, J.; Choulet, F.; Monie, P. Intracontinental subduction: A possible mechanism for the Early Palaeozoic Orogen of SE China. Terra Nova 2009, 21, 360-368. [CrossRef]

104. Li, J.L. Tectonic framework and evolution of southeastern China. J. Southeast Asian Earth Sci. 1993, 8, $219-223$.

105. Liu, Q.; Yu, J.H.; Wang, Q.; Su, B.; Zhou, M.F.; Xu, H.; Cui, X. Ages and geochemistry of granites in the Pingtan-Dongshan Metamorphic Belt, Coastal South China: New constraints on Late Mesozoic magmatic evolution. Lithos 2012, 150, 268-286. [CrossRef]

106. Zheng, Y.F.; Xiao, W.J.; Zhao, G.C. Introduction to tectonics of China. Gondwana Res. 2013, 23, 1189-1206. [CrossRef]

107. Harris, N.B.W.; Pearce, J.A.; Tindle, A.G. Geochemical characteristics of collision-zone magmatism. Geol. Soc. Lond. Spec. Publ. 1986, 19, 67-81. [CrossRef]

108. Pearce, J.A.; Harris, N.B.W.; Tindle, A.G. Trace element discrimination diagrams for the tectonic interpretation of granitic rocks. J. Petrol. 1984, 25, 956-983. [CrossRef]

109. Li, J.H.; Dong, S.W.; Cawood, P.A.; Zhao, G.C.; Johnston, S.T.; Zhang, Y.Q.; Xin, Y.J. An Andean-type retro-arc foreland system beneath northwest South China revealed by SINOPROBE profiling. Earth Planet. Sci. Lett. 2018, 490, 170-179. [CrossRef]

110. Deng, J.F.; Zhao, H.L.; Lai, S.C.; Luo, Z.H. Muscovite/two-mica granite and intracontinental subduction. Earth Sci. 1994, 19, 139-147. (In Chinese with English abstract)

111. Deng, J.F.; Zhao, H.L.; Mo, X.X.; Liu, H.X.; Luo, Z.H. Intracontinental subduction of the Yangtze Continent and Continent reducing-inferred from muscovite (two mica) granites. Geol. J. China Univ. 1995, 1, 50-57. (In Chinese with English abstract)

112. Li, S.Z.; Suo, Y.H.; Li, X.Y.; Wang, Y.M.; Cao, X.Z.; Wang, P.C.; Zhang, G.W. Mesozoic plate subduction in West Pacific and tectono-magmatic response in the East Asian ocean-continent connection zone. Chin. Sci. Bull. 2018, 63, 1550-1593. (In Chinese) [CrossRef]

113. Dong, S.W.; Zhang, Y.Q.; Zhang, F.Q.; Cui, J.J.; Chen, X.H.; Zhang, S.H.; Li, H.L. Late Jurassic-Early Cretaceous continental convergence and intracontinental orogenesis in East Asia: A synthesis of the Yanshan Revolution. J. Asian Earth Sci. 2015, 114, 750-770. [CrossRef] 
114. Dong, S.W.; Zhang, Y.Q.; Gao, R.; Su, J.B.; Liu, M.; Li, J.H. A possible buried Paleoproterozoic collisional orogen beneath central South China: Evidence from seismic-reflection profiling. Precambrian Res. 2015, 264, 1-10. [CrossRef]

115. Li, S.Z.; Santosh, M.; Zhao, G.C.; Zhang, G.W.; Jin, C. Intracontinental deformation in a frontier of super-convergence: A perspective on the tectonic milieu of the South China Block. J. Asian Earth Sci. 2012, 49, 313-329. [CrossRef]

116. Li, L.M.; Sun, M.; Wang, Y.J.; Xing, G.F.; Zhao, G.C.; Lin, S.F.; Wong, J. U-Pb and Hf isotopic study of zircons from migmatised amphibolites in the Cathaysia Block: Implications for the early Paleozoic peak tectonothermal event in Southeastern China. Gondwana Res. 2011, 19, 191-201. [CrossRef]

117. Shi, W.; Zhang, Y.Q.; Dong, S.W.; Hu, J.M.; Wiesinger, M.; Ratschbacher, L.; Li, H.L. Intra-continental Dabashan orocline, southwestern Qinling, Central China. J. Asian Earth Sci. 2012, 46, 20-38. [CrossRef]

118. Chu, Y.; Faure, M.; Lin, W.; Wang, Q.C. Early Mesozoic tectonics of the South China block: Insights from the Xuefengshan intracontinental orogen. J. Asian Earth Sci. 2012, 61, 199-220. [CrossRef]

119. Dong, S.W.; Zhang, Y.Q.; Long, C.X.; Yang, Z.Y.; Ji, Q.; Wang, T.; Chen, X.H. Jurassic tectonic revolution in china and new interpretation of the Yanshan movement. Acta Geosci. Sin. 2007, 81, 1449-1461. (In Chinese with English abstract)

120. Feng, C.Y.; Zeng, Z.L.; Zhang, D.Q.; Qu, W.J.; Du, A.D.; Li, D.X.; She, H.Q. SHRIMP zircon U-Pb and molybdenite Re-Os isotopic dating of the tungsten deposits in the Tianmenshan-Hongtaoling W-Sn ore field, southern Jiangxi Province, China, and geological implications. Ore Geol. Rev. 2011, 43, 8-25. [CrossRef]

121. Feng, Y.F.; Yao, X.F.; Wei, Y.Q.; Ma, T.; Gong, F.Y.; Xing, G.F.; Sun, Y.W. Yanshanian (J-K) TTG rocks assemblage and its geological significance, Changle-Nan'ao tectonic belt. Acta Petrol. Sin. 2014, 30, 3315-3333. (In Chinese with English abstract)

122. He, Z.Y.; Xu, X.S.; Niu, Y. Petrogenesis and tectonic significance of a Mesozoic granite-syenite-gabbro association from inland South China. Lithos 2010, 119, 621-641. [CrossRef]

123. Deng, J.F.; Feng, Y.F.; Di, Y.J.; Liu, C.; Xiao, Q.H.; Su, S.G.; Xiong, L. The intrusive spatial temporal evolutional framework in the Southeast China. Geol. Rev. 2016, 62, 3-16. (In Chinese with English abstract)

124. Deng, J.F.; Liu, C.; Di, Y.J.; Feng, Y.F.; Su, S.G.; Xiao, Q.H.; Duan, P.X. Crustal convergent and accretional consumption zones, and continent-continent collisional orogenes and subduction-accretional orogenes: Records from the igneous petrotectonic assemblages. Earth Sci. Front. 2016, 23, 34-41. (In Chinese with English abstract)

125. Feng, Y.F.; Deng, J.F.; Xiao, Q.H.; Xing, G.F.; Su, S.G.; Cui, X.Y.; Gong, F.Y. Recognizing the TTG Rock types: Discussion and Suggestion. Geol. J. China Univ. 2011, 17, 406-414. (In Chinese with English abstract)

126. Liu, X.C.; Li, S.Z.; Jahn, B.M. Tectonic evolution of the Tongbai-Hong'an orogen in central China: From oceanic subduction/accretion to continent-continent collision. Sci. China Earth Sci. 2015, 58, 1477-1496. [CrossRef]

127. Zhang, Q.; Teyssier, C.; Dunlap, J.; Zhu, G. Oblique collision between North and South China recorded in Zhangbaling and Fucha Shan (Dabie-Sulu transfer zone). In Exhumation Associated with Continental Strike-Slip Fault Systems: Geological Society of America Special Paper; Till, A.B., Roeske, S.M., Sample, J.C., Foster, D.A., Eds.; Geological Society of America: Boulder, CO, USA, 2007; Volume 434, pp. 167-206.

128. Deng, J.F.; Mo, X.X.; Zhao, H.L.; Wu, Z.X.; Luo, Z.H.; Su, S.G. A new model for the dynamic evolution of Chinese lithosphere: 'continental roots-plume tectonics'. Earth-Sci. Rev. 2004, 65, 223-275. [CrossRef] 